\title{
The Effect of Foliar Application of Magnetic Water and Nano-Fertilizers on Phytochemical and Yield Characteristics of Fennel
}

\author{
Shahin Faridvand ${ }^{1}$, Reza Amirnia ${ }^{1, *}$, Mehdi Tajbakhsh ${ }^{1}$, Hesham Ali El Enshasy ${ }^{2,3,4}(\mathbb{D})$ and R. Z. Sayyed ${ }^{5} \mathbb{D}$ \\ 1 Department of Plant Production and Genetics, Faculty of Agriculture, Urmia University, \\ Urmia 5756151818, Iran; qartal53@yahoo.com (S.F.); mtajbakhshurmia@gmail.com (M.T.) \\ 2 Institute of Bioproduct Development (IBD), Universiti Teknologi Malaysia (UTM), Skudai, \\ Johor Bahru 81310, Malaysia; henshasy@ibd.utm.my \\ 3 School of Chemical and Energy Engineering, Universiti Teknologi Malaysia (UTM), Skudai, \\ Johor Bahru 81310, Malaysia \\ 4 City of Scientific Research and Technology Applications (SRTA), New Burg Al Arab, Alexandria 21934, Egypt \\ 5 Department of Microbiology, PSGVP Mandal's Arts, Science and Commerce College, Shahada 425409, India; \\ sayyedrz@gmail.com \\ * Correspondence: r.amirnia@urmia.ac.ir or ramirnia@gmail.com
}

\section{check for} updates

Citation: Faridvand, S.; Amirnia, R.; Tajbakhsh, M.; El Enshasy, H.A.; Sayyed, R.Z. The Effect of Foliar Application of Magnetic Water and Nano-Fertilizers on Phytochemical and Yield Characteristics of Fennel. Horticulturae 2021, 7, 475. https:/ / doi.org/10.3390/horticulturae7110475

Academic Editors:

Jelena Popović-Djordjević and Luiz Fernando Cappa de Oliveira

Received: 12 September 2021

Accepted: 26 October 2021

Published: 8 November 2021

Publisher's Note: MDPI stays neutral with regard to jurisdictional claims in published maps and institutional affiliations.

Copyright: (c) 2021 by the authors. Licensee MDPI, Basel, Switzerland. This article is an open access article distributed under the terms and conditions of the Creative Commons Attribution (CC BY) license (https:// creativecommons.org/licenses/by/ $4.0 /)$.

\begin{abstract}
Environmental factors, especially nutrients, can influence the production of medicinal plants. Thus, the present study assessed the response of some morphological and physiological characteristics of fennel ecotypes to the foliar application (magnetic water, organic and chemical fertilizers). The study was a factorial experiment based on the randomized complete block design, with three replications and 25 treatments at the research farm of the Agricultural and Natural Resources Research and Education Center of West Azerbaijan province, Iran, in the spring and summer of two consecutive years, 2014-2015 and 2015-2016. The first factor was assigned to fennel landraces (Gaziantep, Hamedan, Urmia, Yazd, and Shiraz) and the second factor to the foliar application (nitrogen nano-fertilizer, magnetic water, urea, chicken manure, and the control). Results showed that interaction of fertilizer treatment and landrace increased fresh and dry weight, biological yield, and seed yield significantly. In the first year, the highest fresh weight (166 g) and dry weight $(35.5 \mathrm{~g})$ were observed in the Gaziantep landrace fertilized with chicken manure. The highest anethole and fenchone contents ( $81.75 \%$ and $7.92 \%$, respectively) were observed in the landraces treated with chicken manure. Based on the percentages, the Urmia landrace had the highest anethole percentage $(83.2 \%)$, and the Shiraz landrace had the lowest one $(77.5 \%)$. The highest fenchone contents $(9.61 \%)$ and the lowest $(2.18 \%$ ) were observed in the Yazd and Urmia landraces. Due to the positive effect of application of chicken manure on improving the studied traits of fennel, it is recommended to include chicken manure inputs to enhance the efficiency of crops, reduce environmental pollution, and move toward sustainable agriculture.
\end{abstract}

Keywords: essential oil; chlorophyll; nutrient; anetol

\section{Introduction}

Medicinal plants are precious resources in Iran's broad landscape of natural resources, which can play an essential role in health, employment, and non-petroleum export if recognized, cultivated, developed, and exploited scientifically and correctly [1]. Fennel (Foeniculum vulgare Mill) is an ancient medicinal plant from the family Apiaceae, used as a raw material for different industrial medications [2]. This plant is cultivated and distributed in various Mediterranean regions and the Middle East, including Italy, Turkey, and Iran [3]. Fennel fruits are spindly shaped with narrow ends in green or light brown [4]. The whole body of this plant contains essential oil, but its fruits are the richest source of essential oil. The essential oils are accumulated through channel-shaped structures formed 
by gland cells and distributed across the plant, and their active ingredients are used to heal cough, stomachache, flatulence, and dyspepsia in children and stimulate milk production in mothers [5]. The essential oil content of the fennel (3-5.5\%) is greater than that of other species from the same family [6].

Given the limitation of water resources in Iran, the agricultural sector's use of unconventional water resources has been proposed as a solution. One of these methods is to pass water through a magnetic field before irrigation to improve water productivity [7]. Similar to other living organisms, plants are influenced by the Earth's magnetic field. The application of magnetic fields increases plant growth and development both in vitro and in field conditions. The practical application of magnetic fields has been reported to influence seed germination, seedling development positively, and yields of some plants, such as industrial crops [8,9], medicinal plants [10], fruits and vegetables [11], horticultural plants [12], and trees [13]. The effect of a magnetic field on plant growth and development depends on the magnetic field specifications, such as polarity, intensity, exposure duration, and magnetism type [14]. When water passes through a magnetic field, the hydrogen and Van der Waals bonds between its molecules break, and when the eponymous homonymous parts of water molecules are aligned, they will occupy less space, and consequently, their freedom and mobility will increase, and their surface tension will decrease [15]. In magnetic form, water fluidity increases, its wettability escalates, and it can be absorbed readily. Subsequently, more minerals are supplied to the plants, and their growth and yields are enhanced [16]. Mahmoud and Amira [17] reported that the grain weight, grain yield, and biological yield of bread wheat were higher when treated with $31 \%, 28 \%$, or $25 \%$ magnetic water than when not. According to El Sayed [18], the plant height of fava beans was $27.39 \%$ greater in the non-magnetic water treatment.

Chemical fertilizers have played a significant role in meeting the nutrient requirements of plants and increasing crop yields in the last 30 years. However, the excessive application of them, e.g., urea, has brought about the contamination of groundwater resources, soils, and water resources and the over-accumulation of nitrogen in plant tissues in addition to increasing production costs $[19,20]$. Dahmardeh [21] found that although chemical fertilizers were valuable, production increased to a greater extent when chicken manure was applied. A primary goal of sustainable agriculture is to reduce chemical fertilizers and increase organic fertilizers, especially manures [22]. The application of manures, e.g., chicken manure, satisfy the nutrient requirements of plants and improves soil conditions, plant growth, and seed yield, and it can contribute to ecosystem sustainability in the long run. They can be an excellent supplement for chemical fertilizers if available in large quantities $[23,24]$. In this respect, chicken manure is rich in nutrients. It has other features, such as the gradual release of nitrogen (which can reduce nitrate leaching), gradual release of potassium and calcium compounds (which can be effective in adjusting soil $\mathrm{pH}$ ), and high organic matter content (which can increase water and nutrient retention capacity) [24]. Azzaz et al. [25] revealed that the mixture of organic and biological fertilizers was most effective in increasing fennel plant growth, yield, and oil content. Ahmed and Bistgani et al. [26,27] reported that rose plants exhibited significant differences in their height, number of auxiliary branches, dry weight, and flower yield when treated with chicken manure versus the other fertilizers. Golestaneh et al. [28] found that cattle and chicken manure application to lavender plants changed some of their morphological traits, such as flower number, leaf, seed number, and 1000-seed weight significantly. A research study on safflower showed the significant effect of manure on the number of auxiliary branches, 1000-seed weight, and seed yield versus the control [29]. Al-Enzy et al. [30] found that manure increased most physiological traits of fennel. Moradi et al. [19] found that applying organic fertilizers changed anethole percentage significantly versus fenchone, estragole, and limonene. Similarly, Abbas and Abdul Muttalib [31] showed that anethole content was higher at higher $\mathrm{N}$ fertilizer levels, whereas fenchone content was higher at higher $\mathrm{P}$ fertilization levels. 
A method to reduce the application of chemical fertilizers is to use nano-fertilizers to feed the plants [32]. Research on several plants has improved physiological activities, vegetative growth, protein level, and yield with nano-fertilization [33]. Abdelkader et al. [34] found that nano-fertilizers increased vegetative growth (height, the number of auxiliary branches, and dry weight), seed yield, essential oil yield, P content, and chlorophyll content of fennels. Nano-fertilizers improve nutrient use efficiency and alleviate the likely adverse effects of nutrient toxicity. Thus, nanotechnology has various aspects for accomplishing sustainable agriculture, especially in developed regions [35].

The present study aimed to cast light on the effect of different fertilization solutions and magnetic water on various indigenous and foreign landraces and their comparison with the local landrace (Urmia) of Fennel. An alternative can be found for nitrogen fertilizer to the environmental problems of its excessive application. Conversely, we aimed to compare the yield of different landraces to replace fennel in other cultures in the region to increase farm productivity by changing cropping patterns.

\section{Materials and Methods}

The research was conducted at the research farm (Long. $45^{\circ} 00^{\prime} \mathrm{E}$, Lat. $37^{\circ} 40^{\prime} \mathrm{N}$, elevation $1363 \mathrm{~m}$ from sea level) in the Agricultural and Natural Resources Research and Education Center of Western Azerbaijan province, Iran, to determine the effect of the foliar application of organic fertilizer (chicken manure), inorganic fertilizers ( $\mathrm{N}$ nano-fertilizers and urea), and magnetic water on some morphological traits (fresh and dry weight), physiological traits (chlorophyll $a$ and $b, \mathrm{~N}, \mathrm{P}$, and K content, and essential oil yield), seed yield, and biological yield of fennel landraces.

Before the experiment initiation, the soil of the research farm was sampled from a depth of $0-30 \mathrm{~cm}$ to analyze its chemical and physical features; also, the physical and chemical characteristics of the chicken manure were measured. The results are presented in Tables 1 and 2. The latitude (degree, minute), longitude (degree, minute), and height (meter) of the cities whose landraces were used are presented in Table 3.

Table 1. The physical and chemical characteristics of the soil in the experimental farm.

\begin{tabular}{|c|c|c|c|c|c|c|c|c|c|c|c|}
\hline \multirow[t]{2}{*}{ Year } & \multirow{2}{*}{$\begin{array}{l}\text { Clay } \\
(\%)\end{array}$} & \multirow{2}{*}{$\begin{array}{l}\text { Silt } \\
(\%)\end{array}$} & \multirow{2}{*}{$\begin{array}{c}\text { Sand } \\
(\%)\end{array}$} & \multirow{2}{*}{$\begin{array}{c}\text { O.M } \\
(\%)\end{array}$} & \multirow[t]{2}{*}{$\mathrm{pH}$} & \multicolumn{3}{|c|}{$\begin{array}{l}\text { Available Nutrients } \\
\left(\mathrm{mg} / \mathrm{kg}^{-1}\right)\end{array}$} & \multirow[t]{2}{*}{$\begin{array}{c}\text { EC } \\
\text { Ds/m }\end{array}$} & \multirow{2}{*}{$\begin{array}{l}\text { S.P } \\
(\%)\end{array}$} & \multirow{2}{*}{$\begin{array}{l}\text { TNV } \\
(\%)\end{array}$} \\
\hline & & & & & & $\mathbf{N}$ & $\mathbf{P}$ & $\mathbf{K}$ & & & \\
\hline First & 35.5 & 38 & 26.5 & 2 & 7.9 & 0.2 & 8.15 & 408 & 1.1 & 46 & 15.8 \\
\hline Second & 34 & 38 & 28 & 1.47 & 7.88 & 0.23 & 7.25 & 416 & 1.82 & 47 & 15.1 \\
\hline
\end{tabular}

Table 2. The physical and chemical characteristics of the chicken manure.

\begin{tabular}{cccccccccc}
\hline Year & $\begin{array}{c}\mathbf{C u} \\
\left(\mathbf{m g} / \mathbf{k g}^{-\mathbf{1}}\right)\end{array}$ & $\begin{array}{c}\mathbf{Z n} \\
\left(\mathbf{m g} / \mathbf{k g}^{-\mathbf{1}}\right)\end{array}$ & $\begin{array}{c}\mathbf{K} \\
\left(\mathbf{m g} / \mathbf{k g}^{-\mathbf{1}}\right)\end{array}$ & $\begin{array}{c}\mathbf{P} \\
\left(\mathbf{m g} / \mathbf{k g}^{-\mathbf{1}}\right)\end{array}$ & $\begin{array}{c}\mathbf{N} \\
\left(\mathbf{m g} / \mathbf{k g}^{-\mathbf{1}}\right)\end{array}$ & $\mathbf{p H}$ & $\begin{array}{c}\mathbf{C} / \mathbf{N} \\
\text { Ratio }\end{array}$ & $\begin{array}{c}\text { O.M } \\
(\mathbf{\%})\end{array}$ & $\begin{array}{c}\text { Moisture } \\
(\mathbf{\%})\end{array}$ \\
\hline First & 106.8 & 400 & 20,000 & 17,500 & 50,000 & 7.6 & 12.8 & 34.1 & 28 \\
Second & 103 & 395 & 18,000 & 17,000 & 52,000 & 7.5 & 11.2 & 35 & 30 \\
\hline
\end{tabular}

Table 3. The latitude, longitude, and height of the cities whose landraces were used.

\begin{tabular}{cccccc}
\hline & Shiraz & Yazd & Urmia & Hamadan & Ghazian Tep \\
\hline Longitude (Degrees, minutes) & $34^{\circ} 22^{\prime}$ & $45^{\circ}$ & $48^{\circ} 32^{\prime}$ & $56^{\circ} 36^{\prime}$ & $52^{\circ} 32^{\prime}$ \\
Latitude (Degrees, minutes) & $29^{\circ} 36^{\prime}$ & $33^{\circ} 22^{\prime}$ & $34^{\circ} 5^{\prime}$ & $34^{\circ} 4^{\prime}$ & $46^{\circ} 4^{\prime}$ \\
Height (meter) & 1519 & 1230 & 1363 & 1803 & 859 \\
\hline
\end{tabular}

The soil of the study site was loam-sandy, and its climate was semi-arid. The first factor was assigned to fennel landraces at five levels (including Ghazian tep and the local landraces of Hamadan, Urmia, Yazd, and Shiraz), and the second factor was assigned to the foliar application at five levels (including $\mathrm{N}$ nano-fertilizers, magnetic water, urea, chicken manure, and control). Fertilizer treatments were applied by spraying on the plants. After 
land preparation, the seeds were sown at a depth of $3 \mathrm{~cm}$ in plots with a length of $3 \mathrm{~m}$ on 8 rows with an inter-row spacing of $45 \mathrm{~cm}$ and an on-row spacing of $15 \mathrm{~cm}$. The irrigation was performed by the sprinkler system every seven days, and the plots were regularly weeded. The fertilizers were applied at three stages—bolting initiation, early flowering stage or initiation bolting, and flowering flower.

The magnetic water solution was prepared at a magnetic strength of $200 \mathrm{mT}$ with a Russian SIB8 water magnetization device (U050 mg, 0.5 inches, output $4-6 \mathrm{~m}^{3} / \mathrm{h}, 30 \mathrm{mT}$ L.C.C.) [36]. The nano- $\mathrm{N}$ fertilizer was prepared at a rate of 2:1000 as per the recipe on the label of $25 \%$ nano-N fertilizer procured from Pasargad Mehr Ragbarg Company, Tehran, Iran. An amount of $5 \mathrm{~kg}$ of urea fertilizer was dissolved in $100 \mathrm{~L}$ of water [37]. To produce the chicken manure solution, a mixture of water and chicken manure was prepared at a ratio of 1:10, kept at room temperature for $48 \mathrm{~h}$, shaken, and filtered through two thin pieces of cloth [38]. In both cropping years, morphological traits (fresh and dry weight), physiological traits (chlorophyll $a$ and $b, \mathrm{~N}, \mathrm{P}$, and K contents, and essential oil yield), seed yield, biological yield, and harvest index of the fennel landraces were recorded. To calculate essential oil yield, essential oil percentage was multiplied by the yield of each treatment.

\subsection{Measurement of Essential Oil Content}

To determine essential oil content, $30 \mathrm{~g}$ of dried seeds from the plots were separately ground and extracted by the water-distillation method with a Clevenger for $3 \mathrm{~h}$. Then, essential oil efficiency was calculated based on the sample's dry weight [39].

\subsection{Measurement of Chlorophyll $a$ and $b$ Contents}

To determine chlorophyll $a$ and $b$ contents, $0.2 \mathrm{~g}$ of fresh leaf tissue was gradually crashed with $5 \mathrm{~mL}$ of $80 \%$ acetone in a mortar until the chlorophyll was released into the acetone solution. Then, the solution volume was adjusted to $25 \mathrm{~mL}$. It was then centrifuged at $4000 \mathrm{rpm}$ for $10 \mathrm{~min}$. The absorption of chlorophyll a and b were read with a spectrophotometer at 645 and $663 \mathrm{~nm}$, respectively [40].

\subsection{Measurement of Nitrogen Content}

Nitrogen content was measured by the Kjeldahl method at two stages of digestion and distillation [41]. One gram of ground seeds was mixed with $5 \mathrm{~g}$ of catalyzer (copper sulfate, potassium sulfate, and copper oxide), and it was then added with $20 \mathrm{~mL}$ of $98 \%$ sulfuric acid. The samples were kept at $410{ }^{\circ} \mathrm{C}$ in a Kjeldahl (Gerhardt Company, Bonn, Germany) device for $1.5 \mathrm{~h}$. After they were taken out of the device, $20 \mathrm{~mL}$ of distilled water was added, and then they were titrated with Titrasol sulfuric acid. The amount of acid applied in titration was placed in the following equation to yield nitrogen content.

\subsection{Measurement of Potassium Content}

Potassium content was determined by using a Sherwood 410 flame-photometer and the drawn standard curve [42]. To determine Fennel potassium content, $1 \mathrm{~g}$ of dry ground and meshed sample was placed in a furnace at $550{ }^{\circ} \mathrm{C}$ for $24 \mathrm{~h}$. After digestion by dry burning method (with HCL), the samples were adjusted to $100 \mathrm{~mL}$ using distilled water. Using a Clinical pfp7 flame photometer (Jenway Gransmore Green Felsted, Dunmow Essex, CM6 3LB, ENGLAND, Model 8515), first potassium standards and then the main samples were read by the flame emission method. To prepare the standard, $9.53 \mathrm{~g}$ of potassium chloride was solved in water and its volume was adjusted in a $1 \mathrm{~L}$ volumetric flask (thick standard). Then, for a series of standard solutions, 10, 8, 6, 4, 2, and $0 \mathrm{~mL}$ of the thick standard was poured into $100 \mathrm{~mL}$ volumetric flasks containing $50 \mathrm{~mL}$ of water and $4.5 \mathrm{~mL}$ of thick sulfuric acid, and it was adjusted to the desired volume.

\subsection{Measurement of Phosphorous Content}

Phosphorous content was estimated based on the color intensity of the solutions using a Halo DB-20UV-VIS double-beam spectrophotometer at $470 \mathrm{~m} \mu$ [43]. To measure Fennel 
phosphorus content, $1 \mathrm{~g}$ of the sample was ground and meshed. After it was digested by dry burning (with HCL), it was adjusted to $100 \mathrm{~mL}$ by adding distilled water. Then, $5 \mathrm{~mL}$ of the sample was mixed with $5 \mathrm{~mL}$ of yellow solution (ammonium heptamolybdate + ammonium vanadate) and then its volume was increased to $25 \mathrm{~mL}$ by adding distilled water. After $0.5 \mathrm{~h}$, the samples were filtered through a filter paper and the resulting extract was read at $470 \mathrm{~nm}$ with a spectrophotometer (Spectrophotometer APEL Model PD303UV, Kawaguchi City, Saitama, Japan). First, phosphorus standards and then the main samples were read. To prepare the standard, $2.19 \mathrm{~g}$ of $\mathrm{KH} 2 \mathrm{PO} 4$ was first solved in a slight amount of water and was adjusted in volume in a 1-L volumetric flask (thick standard). For the series of standard solutions, 10, 8, 6, 4, 2, and $0 \mathrm{~mL}$ of the thick standard was taken, and $5 \mathrm{~mL}$ of zinc molybdate ammonium was added and adjusted to $25 \mathrm{~mL}$.

\subsection{Essential Oil Analysis}

The compounds constituting seed essential oil were determined with a chromatograph and gas chromatography-mass spectrometry (GC/MS) in the laboratory of Urmia Academic Center for Education, Culture, and Research. The percentages of essential oil compounds were obtained based on the under-curve area of the chromatograph spectrum derived from GC [44]. Fennel EO was extracted by using the water distillation method. Briefly, $50 \mathrm{~g}$ of dry matter (leaf + flower) from each plot was weighed; briefly ground in $500 \mathrm{~mL}$ water, before boiling in a Clevenger for $3 \mathrm{~h}$ to extract the $\mathrm{EO}$, which was then weighed. The EO content and EO yield were calculated as follows [45]: gas chromatography-mass spectrometry analysis was undertaken using an Agilent 7890/5975C (Santa Clara, CA, USA) GC/MSD. An HP-5MS capillary column (5\% phenyl methyl polysiloxane, $30 \mathrm{~m}$ length, $0.25 \mathrm{~mm}$ id. $0.25 \mu \mathrm{m}$ film thicknesses) was used to separate the EO components. The following oven temperature was applied: $3 \mathrm{~min}$ at $80^{\circ} \mathrm{C}$, before increasing by $8{ }^{\circ} \mathrm{C} / \mathrm{min}$ to $180^{\circ} \mathrm{C}$, and held for $10 \mathrm{~min}$ at $180^{\circ} \mathrm{C}$. Helium was used as the carrier gas at a flow rate of $1 \mathrm{~mL} / \mathrm{min}$. The sample was injected $(1 \mu \mathrm{L})$ in split mode (1:50). The EI mode was $70 \mathrm{Ev}$. Mass range was set from 40 to $550 \mathrm{~m} / \mathrm{z}$. The components were recognized by comparing the calculated Kovats retention indices (RIs), from a mixture of n-alkaneseries (C8-C30, Supelco, Bellefonte, CA, USA) and mass spectra [44]. GC-FID analysis was undertaken with an Agilent 7890 an instrument. Separation was performed in an HP-5 capillary column. The analytical conditions were the same as above. Quantification methods were the same as those reported by Morshedloo et al. [46].

\subsection{Statistical Analysis}

The SAS (v9.4) software package analyzed data, and the means were compared by Duncan's multiple range test at the $1 \%$ and $5 \%$ levels.

\section{Results and Discussion}

Tables 4 and 5 show the analysis of variance related to the traits measured in this study.

\subsection{Fresh and Dry Weight}

Results in Table 6 show that the highest fresh weight (166 g) and dry weight (35 g) were obtained from the Ghaziantep plants treated with chicken manure in 2014, which increased $153 \%$ and $218 \%$, respectively, compared to 2015 , such that the lowest fresh weight $(65.5 \mathrm{~g})$ and dry weight $(11 \mathrm{~g})$ were related to the Ghaziantep plants in the control treatment in 2015. The significant increase in chicken manure's fresh and dry weight may be related to the extension of the growth period and the retardation of harvest time [47]. Organic manures are slow releaser and provide nutrients throughout growth period [48]. 
Table 4. Complete analysis of variance (mean squares) for the measured traits of sweet fennel.

\begin{tabular}{ccccccc}
\hline $\begin{array}{c}\text { Sources of } \\
\text { Variance }\end{array}$ & df & $\begin{array}{c}\text { Oil Yield } \\
\mathbf{( k g / h a )}\end{array}$ & $\begin{array}{c}\text { Biological } \\
\text { Yield } \\
\mathbf{( k g / h a )}\end{array}$ & $\begin{array}{c}\text { Seed Yield } \\
\mathbf{( k g} / \mathbf{h a})\end{array}$ & $\begin{array}{c}\text { Dry } \\
\text { Weight } \\
\mathbf{( g )}\end{array}$ & $\begin{array}{c}\text { Fresh } \\
\text { Weight } \\
\mathbf{( g )}\end{array}$ \\
\hline $\mathrm{Y}$ & 1 & $224.4^{* *}$ & $26,779,317^{* *}$ & $3,734,179^{* *}$ & $124.2^{* *}$ & $2468^{* *}$ \\
$\mathrm{R} \times \mathrm{Y}$ & 2 & $29.07^{* *}$ & $1,612,841^{* *}$ & $4,9095^{* *}$ & $3.2 \mathrm{~ns}$ & $59.4 \mathrm{~ns}$ \\
$\mathrm{~L}$ & 4 & $406.8^{* *}$ & $3,954,296^{* *}$ & $267,121^{* *}$ & $101.9^{* *}$ & $541.9^{* *}$ \\
$\mathrm{~T}$ & 4 & $117.7^{* *}$ & $4,252,999^{* *}$ & $188,794^{* *}$ & $31.9^{*}$ & $407.8^{* *}$ \\
$\mathrm{~L} \times \mathrm{T}$ & 16 & $44.52^{* *}$ & $2,127,966^{* *}$ & $9,6580^{* *}$ & $97.7^{* *}$ & $1439.5^{* *}$ \\
$\mathrm{~T} \times \mathrm{Y}$ & 4 & $99.95^{* *}$ & $5,441,764^{* *}$ & $200,400^{* *}$ & $350.3^{* *}$ & $3234.1^{* *}$ \\
$\mathrm{~T} \times \mathrm{Y}$ & 4 & $57.97^{* *}$ & $783,887^{*} \mathrm{~ns}$ & $43,057^{* *}$ & $80.1^{* *}$ & $93.7^{* *}$ \\
$\mathrm{~L} \times \mathrm{T} \times \mathrm{Y}$ & 16 & $45.88^{* *}$ & $2,123,625^{* *}$ & $113,983^{* *}$ & $75.2^{* *}$ & $979.9^{* *}$ \\
Error & 96 & 8.34 & 505,972 & 1,2469 & 3.9 & 61.3 \\
$\mathrm{CV}(\%)$ & & 13.08 & 19.69 & 10.76 & 10.8 & 8.16 \\
\hline
\end{tabular}

**, significant at $\alpha, 1 \%{ }^{*}$, significant at $\alpha, 5 \%$; ns, non-significant; L, landrace; T, treatment; Y, year; R-replication, $\mathrm{df}$ - degree freedom; CV-coefficient of variation

Table 5. Complete analysis of variance (mean squares) for the measured traits of sweet fennel.

\begin{tabular}{|c|c|c|c|c|c|c|}
\hline $\begin{array}{l}\text { Sources of } \\
\text { Variance }\end{array}$ & Df & $\begin{array}{c}P \\
\text { (kg/ha) }\end{array}$ & $\begin{array}{c}\mathrm{K} \\
\text { (kg/ha) }\end{array}$ & $\begin{array}{c}\mathrm{N} \\
\text { (kg/ha) }\end{array}$ & $\begin{array}{c}\text { Chlorophyll } a \\
\text { (kg/ha) }\end{array}$ & $\begin{array}{c}\text { Chlorophyll } b \\
\text { (kg/ha) }\end{array}$ \\
\hline $\mathrm{Y}$ & 1 & $188.1^{* *}$ & $1450.8^{* *}$ & $4996.3^{* *}$ & $666.1^{* *}$ & $13834^{* *}$ \\
\hline $\mathrm{R} \times \mathrm{Y}$ & 2 & $1.2 \mathrm{~ns}$ & $15.1 \mathrm{~ns}$ & $72.7^{* *}$ & $48.1 *$ & $74.4 \mathrm{~ns}$ \\
\hline $\mathrm{L}$ & 4 & $20.1^{* *}$ & $377.8^{* *}$ & $573.4^{* *}$ & $391.4^{* *}$ & $998.2 * *$ \\
\hline $\mathrm{T}$ & 4 & $11.9^{* *}$ & $54.4^{* *}$ & $299.9^{* *}$ & $627.4^{* *}$ & $1706.6^{* *}$ \\
\hline $\mathrm{L} \times \mathrm{T}$ & 16 & $6.8^{* *}$ & $112.3^{* *}$ & $183.5^{* *}$ & $462.6^{* *}$ & $778.5^{* *}$ \\
\hline $\mathrm{T} \times \mathrm{Y}$ & 4 & $13.2 * *$ & $149.7^{* *}$ & $297.9^{* *}$ & $549.8^{* *}$ & $1531^{* *}$ \\
\hline $\mathrm{T} \times \mathrm{Y}$ & 4 & $4.9 * *$ & $155.6^{* *}$ & $149 * *$ & 56.5 * & $222^{* *}$ \\
\hline $\mathrm{L} \times \mathrm{T} \times \mathrm{Y}$ & 16 & $4.4^{* *}$ & $134.1^{* *}$ & $172.9^{* *}$ & $218.7^{* *}$ & $675.9 * *$ \\
\hline Error & 96 & 0.71 & 5.03 & 15.5 & 19.3 & 36.4 \\
\hline CV (\%) & & 13.8 & 11.5 & 11.4 & 13.1 & 10.9 \\
\hline
\end{tabular}

Table 6. The effect of different sources of fertilizer and magnetic water on plant dry weight and fresh weight of sweet fennel in 2014-2015 and 2015-2016 years.

\begin{tabular}{|c|c|c|c|c|c|c|c|c|c|c|}
\hline \multirow[t]{2}{*}{ Treatments } & \multicolumn{5}{|c|}{$\begin{array}{l}\text { Dry Weight } \\
\text { Ecotype }\end{array}$} & \multicolumn{5}{|c|}{$\begin{array}{l}\text { Fresh Weight } \\
\text { Ecotype }\end{array}$} \\
\hline & Qaziantep & Hamadan & Urmia & Yazd & Shiraz & Qaziantep & Hamadan & Urmia & Yazd & Shiraz \\
\hline \multicolumn{11}{|c|}{2014} \\
\hline Nano Nitrogen & $100^{e-m}$ & $121.6^{\mathrm{cd}}$ & $104^{\mathrm{d}-\mathrm{k}}$ & $99^{h-p}$ & $91^{m-p}$ & $26.7^{\text {de }}$ & $23.9^{\mathrm{d}-\mathrm{h}}$ & $18.5^{\mathrm{j}-\mathrm{n}}$ & $16^{n-p}$ & $22.9^{\mathrm{e}-\mathrm{j}}$ \\
\hline Magnetic Water & $126^{\mathrm{bc}}$ & $71.4^{\mathrm{p}-\mathrm{s}}$ & $143^{b}$ & $62^{j-q}$ & $87^{\mathrm{j}-\mathrm{q}}$ & $31^{b c}$ & $12.6^{\mathrm{o}-\mathrm{t}}$ & $17^{\mathrm{i}-\mathrm{n}}$ & $11^{\mathrm{m}-\mathrm{o}}$ & $21.4^{\mathrm{f}-\mathrm{l}}$ \\
\hline Urea & $100^{\mathrm{e}-\mathrm{m}}$ & $95.4^{\mathrm{g}-\mathrm{n}}$ & $117^{\mathrm{c}-\mathrm{e}}$ & $85^{\mathrm{e}-\mathrm{m}}$ & $100^{\mathrm{e}-\mathrm{m}}$ & $23.8^{\mathrm{d}-\mathrm{h}}$ & $14.7^{\mathrm{n}-\mathrm{r}}$ & $21.5^{\mathrm{f}-1}$ & $19^{\mathrm{r}-\mathrm{t}}$ & $21.8^{\mathrm{f}-\mathrm{k}}$ \\
\hline Chicken Manure & $166^{\mathrm{a}}$ & $116.3^{c-f}$ & $70 \mathrm{q}-\mathrm{s}$ & $91^{\mathrm{s}}$ & $89^{\mathrm{i}-\mathrm{q}}$ & $35.5^{\mathrm{a}}$ & $20.7^{g-m}$ & $18.4^{\mathrm{j}-\mathrm{n}}$ & $20^{i-n}$ & $21^{\mathrm{f}-1}$ \\
\hline Control & $91^{h-p}$ & $76.3^{\mathrm{n}-\mathrm{s}}$ & $110^{c-h}$ & $87^{\mathrm{k}-\mathrm{r}}$ & $95^{g-n}$ & $24^{\mathrm{d}-\mathrm{h}}$ & $15.3^{n-q}$ & $23.1^{\mathrm{d}-\mathrm{i}}$ & $23^{h-m}$ & $16^{\mathrm{m}-\mathrm{o}}$ \\
\hline Main B & 116.6 & 96.2 & 108.8 & 84.8 & 92.4 & 28.4 & 17.5 & 19.7 & 17.8 & 20.6 \\
\hline \multicolumn{11}{|c|}{2015} \\
\hline Nano Nitrogen & $80^{\mathrm{m}-\mathrm{s}}$ & $77^{n-s}$ & $82.5^{1-r}$ & $101^{\mathrm{e}-1}$ & $109^{c-i}$ & $18.3^{\mathrm{k}-\mathrm{n}}$ & $14.3^{\mathrm{n}-\mathrm{s}}$ & $18.6^{\mathrm{i}-\mathrm{n}}$ & $25^{\mathrm{d}-\mathrm{f}}$ & $28^{b-d}$ \\
\hline Magnetic Water & $83^{1-r}$ & $91^{h-p}$ & $92.5^{\mathrm{e}-\mathrm{m}}$ & $122^{c-d}$ & $81^{1-\mathrm{s}}$ & $15.2^{n-q}$ & $20.8^{g-m}$ & $22^{\mathrm{f}-\mathrm{k}}$ & $27^{c-e}$ & $9.4^{\mathrm{t}}$ \\
\hline Urea & $77^{\mathrm{n}-\mathrm{s}}$ & $92^{\mathrm{h}-\mathrm{o}}$ & $96.7^{\mathrm{f}-\mathrm{n}}$ & $126^{c}$ & $81^{1-s}$ & $15.5^{n-p}$ & $20.7^{g-m}$ & $24^{d-h}$ & $24^{d-h}$ & $16^{\mathrm{m}-\mathrm{o}}$ \\
\hline Chicken Manure & $83.5^{\mathrm{k}-\mathrm{r}}$ & $113^{c-g}$ & $89.4^{\mathrm{h}-\mathrm{q}}$ & $87^{\mathrm{j}-\mathrm{r}}$ & $74^{\mathrm{o}-\mathrm{s}}$ & $14.3^{\mathrm{n}-\mathrm{s}}$ & $31.3^{b}$ & $11.4^{\mathrm{p}-\mathrm{t}}$ & $14^{\mathrm{n}-\mathrm{s}}$ & $12^{o-t}$ \\
\hline Control & $65.6^{\mathrm{r}-\mathrm{s}}$ & $106^{\mathrm{d}-\mathrm{g}}$ & $101^{\mathrm{e}-1}$ & $77^{\mathrm{n}-\mathrm{s}}$ & $70^{q-s}$ & $11^{\mathrm{q}-\mathrm{t}}$ & $25.2^{\mathrm{d}-\mathrm{g}}$ & $22^{\mathrm{f}-\mathrm{k}}$ & $21^{\mathrm{f}-\mathrm{l}}$ & $10.2^{\text {st }}$ \\
\hline Main B & 77.8 & 95.8 & 72.5 & 103 & 83 & 14.9 & 22.53 & 19.6 & 21.9 & 15.2 \\
\hline
\end{tabular}

Similar letters above the values show non-significant difference at $p<0.05$ by Duncan test.

Furthermore, chicken manure is released gradually and satisfies the nutrient requirements throughout the growth period. The interactions of the factors (Table 6) reveal that the dry and fresh weights of the fennels were influenced by time. 
Zhou et al. [49] reported that the vegetation growth of radish and pakchoi luffa plants increased when treated with organic fertilizers versus chemical fertilizers. These fertilizers are rich in nitrogen, increasing photosynthesis rate, increasing fresh and dry weight [50,51]. Organic manures would have provided micronutrients such as $\mathrm{Fe}, \mathrm{Zn}, \mathrm{Cu}, \mathrm{Mn}$ and $\mathrm{Mg}$ at an optimum level. Copper and manganese are important coenzymes for certain respiratory reactions. Iron is involved in the chlorophyll synthesis pathway. Zinc is involved in the biochemical synthesis of most important phytohormones. Magnesium is involved in chlorophyll synthesis, which in turn increases the rate of photosynthesis [52]. The promoting effect of organic manure on growth of fennel plants may be attributed to the role of organic fertilizer in physiological and biological process as a source of N, P, S and contains high content of B and Mo [53].

Shabrangi and Majd [54] reported that the increases in biomass and fresh weight required metabolic changes, especially in protein biosynthesis. Abdul Qados and Hozayn [16] ascribed the effect of magnetic water on growth to the stimulation of cell metabolism and mitosis. According to Olowoake and Adeoye [55], the effect of cattle manure on corn was similar to the effect of chemical fertilizer. The fresh weight of plants may be related to the high nutrient content of organic fertilizers [56]. These findings are consistent with the literature reports of [57-59].

\subsection{Fruit Yield and Biological Yield}

The results in Table 7 indicate that the different sources of foliar application had significant effects on seed and biological yields in both years. The highest seed yield $(2039 \mathrm{~kg} / \mathrm{ha})$ and biological yield $(7604 \mathrm{~kg} / \mathrm{ha}$ ) were obtained from the Ghaziantep landrace treated with magnetic water in the first year, which increases $235 \%$ and $272 \%$ respectively compared to 2015. Conversely, the lowest seed yield $(608 \mathrm{~kg} / \mathrm{ha})$ was observed in Ghaziantep treated with urea, and the lowest biological yield $(2040 \mathrm{~kg} / \mathrm{ha})$ was observed in Yazd treated with the control, both in the second year. These results show improvements in photosynthesis, hormone balance, growth parameters, and Transmission efficiency translocation efficiency of the plants treated with magnetic water $[17,60]$. These findings are consistent with the literature reports [61-67] respective to green cumin, fennel, celery, and black cumin.

Table 7. The effect of different sources of fertilizer and magnetic water on fruit yield and biological yield of sweet fennel in 2014-2015 and 2015-2016 cropping years.

\begin{tabular}{|c|c|c|c|c|c|c|c|c|c|c|}
\hline \multirow[t]{2}{*}{ Treatments } & \multicolumn{5}{|c|}{$\begin{array}{l}\text { Fruit Yield (kg/ha) } \\
\text { Ecotype }\end{array}$} & \multicolumn{5}{|c|}{$\begin{array}{l}\text { Biological Yield (kg/ha) } \\
\text { Ecotype }\end{array}$} \\
\hline & Qaziantep & Hamadan & Urmia & Yazd & Shiraz & Qaziantep & Hamadan & Urmia & Yazd & Shiraz \\
\hline \multicolumn{11}{|c|}{2014} \\
\hline Nano Nitrogen & $1728^{b}$ & $1369^{\mathrm{cd}}$ & $1067^{\mathrm{e}-\mathrm{n}}$ & $1317^{\mathrm{c}-\mathrm{f}}$ & $1227^{c-g}$ & $5003^{b-c}$ & $4848^{b-i}$ & $3234^{c-j}$ & $4454^{\mathrm{b}-\mathrm{f}}$ & $4364^{b-j}$ \\
\hline Magnetic Water & $2039^{a}$ & $1118^{\mathrm{dk}}$ & $952^{\mathrm{j}-\mathrm{o}}$ & $1051^{\mathrm{f}-\mathrm{o}}$ & $1303^{c-e}$ & $7604^{a}$ & $4068^{b-i}$ & $2785^{h-j}$ & $3870^{c-j}$ & $4765^{b-c}$ \\
\hline Urea & $892^{\mathrm{k}-\mathrm{r}}$ & $1426^{c}$ & $1082^{e-n}$ & $914^{\mathrm{k}-\mathrm{r}}$ & $1340^{c-i}$ & $2438^{h-j}$ & $5719^{b}$ & $3492^{c-j}$ & $2111^{g-j}$ & $3326^{b-c}$ \\
\hline Chicken Manure & $1294^{\mathrm{c}-\mathrm{h}}$ & $1050^{\mathrm{e}-\mathrm{o}}$ & $1091^{\mathrm{d}-\mathrm{m}}$ & $830^{\mathrm{k}-\mathrm{r}}$ & $1283^{c-f}$ & $4845^{b-d}$ & $3586^{c-j}$ & $2412^{h-j}$ & $2745^{\mathrm{f}-\mathrm{g}}$ & $4454^{\mathrm{b}-\mathrm{f}}$ \\
\hline Control & $1048^{\mathrm{e}-\mathrm{n}}$ & $1231^{\mathrm{c}-\mathrm{j}}$ & $1013^{h-q}$ & $876^{\mathrm{k}-\mathrm{r}}$ & $1318^{\mathrm{g}-\mathrm{p}}$ & $3477^{c-j}$ & $3942^{b-i}$ & $3543^{c-j}$ & $2888^{e-j}$ & $5001^{b-c}$ \\
\hline Main B & 1400 & 1239 & 1041 & 998 & 1294 & 3072 & 4433 & 3093 & 3214 & 4382 \\
\hline \multicolumn{11}{|c|}{2015} \\
\hline Nano Nitrogen & $1029^{g-p}$ & $819^{\mathrm{i}-\mathrm{r}}$ & $860^{k-r}$ & $886^{\mathrm{k}-\mathrm{r}}$ & $968^{j-q}$ & $2727^{f-j}$ & $3345^{c-j}$ & $3399^{c-j}$ & $4145^{b-h}$ & $3157^{c-j}$ \\
\hline Magnetic Water & $874^{\mathrm{k}-\mathrm{r}}$ & $1104^{d-f}$ & $857^{\mathrm{k}-\mathrm{r}}$ & $899^{\mathrm{k}-\mathrm{r}}$ & $975^{j-q}$ & $3468^{c-j}$ & $3088^{d-j}$ & $3632^{c-j}$ & $3598^{c-j}$ & $3630^{c-j}$ \\
\hline Urea & $608^{\mathrm{k}-\mathrm{r}}$ & $914^{\mathrm{k}-\mathrm{r}}$ & $822^{\mathrm{i}-\mathrm{r}}$ & $998^{\mathrm{i}-\mathrm{q}}$ & $765^{q-r}$ & $4092^{b-r}$ & $3642^{c-j}$ & $2437^{h-j}$ & $3930^{b-j}$ & $3222^{c-j}$ \\
\hline Chicken Manure & $1016^{\mathrm{h}-\mathrm{q}}$ & $875^{\mathrm{k}-\mathrm{r}}$ & $1028^{g-p}$ & 737 p-r & $634^{\mathrm{r}}$ & $3241^{c-j}$ & $2275^{h-j}$ & $3579^{c-j}$ & $3083^{d-j}$ & $2235^{i-j}$ \\
\hline Control & $788^{\mathrm{n}-\mathrm{r}}$ & $796^{\mathrm{m}-\mathrm{r}}$ & $907^{\mathrm{k}-\mathrm{r}}$ & 725 q-r & $813^{1-r}$ & $2889^{e-j}$ & $2763^{\mathrm{f}-\mathrm{j}}$ & $2917^{c-j}$ & $2040^{j}$ & $2861^{\mathrm{f}-\mathrm{j}}$ \\
\hline Main B & 863 & 902 & 895 & 849 & 831 & 3283 & 3023 & 3193 & 3359 & 3021 \\
\hline
\end{tabular}

Similar letters above the values show non-significant difference at $p<0.05$ by Duncan test.

Hozayn and Qados [68] found that magnetic water improved stomata conductance and nutrient assimilation. Magnetic water reportedly has several physical and chemical 
characteristics, such as polarity, surface tension, $\mathrm{pH}$, electrical conductivity, and solubility [69], improving plant growth.

The higher seed yield in the first year may be associated with the optimal temperature. Since the Ghaziantep landrace outperformed the other studied landraces in growth parameters, it can be inferred that it had a higher seed yield, with the literature reports [70]. El-Abd et al. [71] emphasized that Spraying at the time of inflorescence foliar application during inflorescence had a significant effect on increasing fennel yield. The foliar application of mineral nutrients offers a method of supplying nutrients to higher plants that are more efficiently than methods involving root application when soil conditions are not suitable for nutrients availability [72]. Flower yield in the first year was greater than that in the second year [73].

\subsection{Chlorophyll $a$ and $b$}

According to Table 8, the chlorophyll $a$ and $b$ contents of the fresh leaves of fennel were significantly influenced by foliar application. The Ghaziantep landrace treated with magnetic water in the first year exhibited the highest chlorophyll- $a(116.2 \mathrm{~kg} / \mathrm{ha})$ and chlorophyll $b(65.5 \mathrm{~kg} / \mathrm{ha})$ contents while the Yazd landrace treated with control in the second year exhibited the lowest chlorophyll $a$ content $(23.8 \mathrm{~kg} / \mathrm{ha})$ and the Shiraz landrace treated with chicken manure in the second year exhibited the lowest chlorophyll $b$ content (18 kg/ha). Chloroplast has paramagnetic properties [74]. The magnetic movement of ions in a magnetic field is toward the downside of the field. The magnetic field has a remarkable impact on plants such that it increases energy. Chlorophyll enhancement can be attributed to increased ion fluidity and uptake in the magnetic field, which increases chlorophyll pigments, chlorophyll activity, translocation efficiency, and photo assimilation in the plant [75,76]. Sadeghipour and Aghaei [77] found that irrigation with magnetic water increased leaf area and photosynthesis rate, resulting in more assimilates for vegetative growth, which the increase in chlorophyll content can explain. Chloroplast contains pigments whose structure and position are affected by external factors [78]. The magnetic field makes oriented chloroplast and its elements directional. The same phenomenon is observed in solid objects (ions) and changes the absorption intensity. When a plant is exposed to an external magnetic field, the energy of its paramagnetic materials is increased, and this can activate plant hormones [79]. Research shows that a magnetic field influences photosynthesis mainly through increasing chlorophyll, not other plant carotenoids [80]. After the treatment with the magnetic field, the difference in the interception of short-wavelength waves was clearly shown with chlorophyll $b$. The treatment with the magnetic field influenced chlorophyll, thereby increasing the quality and germination of non-standard seeds [81]. This response can be explained by the presence of some paramagnetic elements in the chloroplast. The magnetic field decreases the effect of carotenoids and increases the share of chlorophyll $b$ in absorption. To study the biochemical changes in chlorophyll under the effect of a magnetic field, Racuciu et al. [80] measured all carotenoids and nucleic acids involved in chlorophyll formation and found that the amount of nucleic acids was increased in the treatments with a low-power magnetic field. However, it was not observed in the treatments with a high-power magnetic field. In another study, Aladjadjiyan [79] explored the effect of magnetic field on the absorption of light spectrum by the photosynthesis system in several perennial ornamental plants and showed that the magnetic field changed the spectral absorption in all samples in both domains of absorption by pigments. Hence, it directly affected the photosynthesis system. 
Table 8. The effect of different sources of fertilizer and magnetic water on chlorophyll $a$ and $b$ of sweet fennel plants in 2014-2015 and 2015-2016 cropping years.

\begin{tabular}{|c|c|c|c|c|c|c|c|c|c|c|}
\hline \multirow{2}{*}{ Treatments } & \multicolumn{5}{|c|}{$\begin{array}{c}\text { Chlorophyll } a \\
\text { Ecotype }\end{array}$} & \multicolumn{5}{|c|}{$\begin{array}{c}\text { Chlorophyll } b \\
\text { Ecotype }\end{array}$} \\
\hline & Qaziantep & Hamadan & Urmia & Yazd & Shiraz & Qaziantep & Hamadan & Urmia & Yazd & Shiraz \\
\hline \multicolumn{11}{|c|}{2014} \\
\hline Nano Nitrogen & $67^{\mathrm{e}-\mathrm{i}}$ & $79.6^{b-d}$ & $52.1^{\mathrm{j}-\mathrm{o}}$ & $78^{b-e}$ & $72^{c-g}$ & $40.2^{\mathrm{e}-\mathrm{i}}$ & $47.6^{\mathrm{de}}$ & $27.8^{\mathrm{j}-\mathrm{O}}$ & $54^{\mathrm{cd}}$ & $29^{\mathrm{m}-\mathrm{r}}$ \\
\hline Magnetic Water & $116^{\mathrm{a}}$ & $71.8^{c-g}$ & $44.7^{\mathrm{k}-\mathrm{p}}$ & $70^{\mathrm{d}-\mathrm{h}}$ & $76.4^{\mathrm{c}-\mathrm{e}}$ & $65.6^{\mathrm{a}}$ & $40.4^{\mathrm{e}-\mathrm{t}}$ & $24.3^{i-n}$ & $38^{\mathrm{f}-1}$ & $31^{\mathrm{i}-\mathrm{r}}$ \\
\hline Urea & $33^{p-u}$ & $109^{a}$ & $58.6^{\mathrm{h}-\mathrm{j}}$ & $40^{\mathrm{o}-\mathrm{s}}$ & $81.6^{b c}$ & $20^{s-u}$ & $57.6^{\mathrm{bc}}$ & $38.2^{\mathrm{f}-\mathrm{j}}$ & $18^{\mathrm{u}}$ & $37^{\mathrm{f}-\mathrm{m}}$ \\
\hline Chicken Manure & $73^{c-f}$ & $56.3^{\mathrm{ik}}$ & $32.3 \mathrm{q}-\mathrm{u}$ & $36^{\mathrm{p}-\mathrm{t}}$ & $68.6^{\mathrm{d}-\mathrm{h}}$ & $42.3^{\mathrm{e}-\mathrm{g}}$ & $41.1^{\mathrm{e}-\mathrm{i}}$ & $19.5^{\text {tu }}$ & $33^{\text {iq }}$ & $21^{\mathrm{f}-1}$ \\
\hline Control & $55^{\mathrm{il}}$ & $62^{f-j}$ & $58.5^{h-j}$ & $43^{\mathrm{m}-\mathrm{r}}$ & $87.5^{b}$ & $26.9^{\mathrm{o}-\mathrm{t}}$ & $23.8^{\mathrm{r}-\mathrm{u}}$ & $27.5^{\mathrm{n}-\mathrm{t}}$ & $30^{\mathrm{k}-\mathrm{r}}$ & $33^{n-p}$ \\
\hline Main B & 68.8 & 62.5 & 49.3 & 53.4 & 77.4 & 42.1 & 42.5 & 27.5 & 34.6 & 30.2 \\
\hline \multicolumn{11}{|c|}{2015} \\
\hline Nano Nitrogen & $31^{\mathrm{r}-\mathrm{u}}$ & $51.7^{\mathrm{j}-\mathrm{o}}$ & 53 jn & $50.6^{\mathrm{i}-\mathrm{o}}$ & $43.5^{1-q}$ & $23.1^{\mathrm{r}-\mathrm{u}}$ & $39.2^{c-j}$ & $33.9^{g-o}$ & $63^{\mathrm{ab}}$ & $22^{\mathrm{r}-\mathrm{u}}$ \\
\hline Magnetic Water & $53.7^{\mathrm{j}-\mathrm{m}}$ & $44.7^{\mathrm{k}-\mathrm{p}}$ & $58.3^{h-j}$ & $59^{h-j}$ & $51.5^{\mathrm{j}-\mathrm{o}}$ & $39.3^{e-j}$ & $29.1^{\mathrm{m}-\mathrm{r}}$ & $36.7^{\mathrm{f}-\mathrm{m}}$ & $40^{\mathrm{e}-\mathrm{i}}$ & $26^{o-u}$ \\
\hline Urea & $58.5^{h-j}$ & $60.8^{g-j}$ & $33.2^{\mathrm{p}-\mathrm{u}}$ & $58.7^{h-j}$ & $52^{\mathrm{j}-\mathrm{o}}$ & $37.9^{\mathrm{f}-\mathrm{k}}$ & $38.2^{\mathrm{f}-\mathrm{j}}$ & $27.5^{\mathrm{n}-\mathrm{t}}$ & $36^{\mathrm{g}-\mathrm{n}}$ & $29^{1-r}$ \\
\hline Chicken Manure & $41.3^{n-s}$ & $27.3^{\text {tu }}$ & $54.5^{\mathrm{i}-\mathrm{l}}$ & $38.9 \mathrm{p}-\mathrm{s}$ & $30.5^{\mathrm{s}-\mathrm{u}}$ & $28.6^{\mathrm{m}-\mathrm{s}}$ & $23.9^{r-u}$ & $38.2^{\mathrm{f}-\mathrm{j}}$ & $42^{\mathrm{e}-\mathrm{h}}$ & $18^{\mathrm{u}}$ \\
\hline Control & $41.3^{\mathrm{n}-\mathrm{s}}$ & $40.3^{\mathrm{o}-\mathrm{s}}$ & $40.4^{\mathrm{o}-\mathrm{s}}$ & $23.8^{\mathrm{u}}$ & $42.6^{\mathrm{m}-\mathrm{r}}$ & $24.9 \mathrm{p}-\mathrm{u}$ & $19.9^{\text {tu }}$ & $23^{r-u}$ & $20^{\text {tu }}$ & $25^{\mathrm{p}-\mathrm{u}}$ \\
\hline Main B & 45.2 & 45 & 47.9 & 46.2 & 44 & 30.8 & 30 & 31.9 & 40 & 24 \\
\hline
\end{tabular}

Similar letters above the values show non-significant difference at $p<0.05$ by Duncan test.

\subsection{Essential Oil Yield}

The highest essential oil yield ( $38.8 \mathrm{~kg} / \mathrm{ha}$ ) was obtained from Ghazian tep treated with magnetic water in the first year, and the lowest $(12.3 \mathrm{~kg} / \mathrm{ha})$ from Hamadan treated with control in the second year (Table 9). It is observed that the maximum essential oil yield was three times as great as the minimum one. The foliar application of manure and chemical fertilizer increased this trait versus the control significantly (Table 9). The local landraces of fennel differed significantly in essential oil yield such that the mean essential oil yield of Urmia in two years $(21.87 \mathrm{~kg} / \mathrm{ha})$ was $38 \%$ higher than that of Hamadan $(15.95 \mathrm{~kg} / \mathrm{ha})$. Although Hamadan had a higher seed yield (Table 9), its essential oil yield was lower than the other landraces due to its lower essential oil percentage. Other landraces had significant differences from Hamadan (Table 6). As is evident in Table 9, the essential oil yield in the first year was $15 \%$ higher than that in the second year $(23.9 \mathrm{~kg} / \mathrm{ha}$ versus $20.8 \mathrm{~kg} / \mathrm{ha}$ ). Since nutrients are the raw material for essential oil production, as they increase, leaf photosynthesis increases, resulting in the production of essential oil per unit area. Mohsen and Kassem [82] reported that magnetic water treatment increased essential oil significantly compared to the control due to magnetic water's higher water and nutrient uptake.

Table 9. The effect of some different sources of fertilizer and magnetic water on nitrogen content and essential oil of sweet fennel plants in 2014-2015 and 2015-2016 cropping years.

\begin{tabular}{|c|c|c|c|c|c|c|c|c|c|c|}
\hline \multirow[t]{2}{*}{ Treatments } & \multicolumn{5}{|c|}{$\begin{array}{l}\text { Nitrogen Content } \\
\text { Ecotype }(\mathrm{mg} / \mathrm{g})\end{array}$} & \multicolumn{5}{|c|}{$\begin{array}{l}\text { Essential Oil } \\
\text { Ecotype }\end{array}$} \\
\hline & Qaziantep & Hamadan & Urmia & Yazd & Shiraz & Qaziantep & Hamadan & Urmia & Yazd & Shiraz \\
\hline \multicolumn{11}{|c|}{2014} \\
\hline Nanonitrogen & $39^{a}$ & $34.4^{b-g}$ & $34.4^{b-g}$ & $33.3^{c-j}$ & $32.9^{\mathrm{d}-\mathrm{j}}$ & $34^{\mathrm{h}}$ & $19.8^{\mathrm{g}-\mathrm{k}}$ & $24.7^{\mathrm{c}-\mathrm{f}}$ & $27^{\mathrm{cd}}$ & $23^{d-g}$ \\
\hline Magnetic Water & $38.3^{a}$ & $32.8^{e-j}$ & $32.4^{\mathrm{f}-\mathrm{k}}$ & 32.5 & $31.4^{\mathrm{i}-\mathrm{W}}$ & $38.8^{a}$ & $14.7^{1-\mathrm{o}}$ & $23.3^{d-g}$ & $21^{\mathrm{f}-\mathrm{j}}$ & $23^{d-g}$ \\
\hline Urea & $32.4^{\mathrm{f}-\mathrm{k}}$ & $34^{\mathrm{b}-\mathrm{h}}$ & $33.2^{c-j}$ & 31.9 & $33.1^{\mathrm{d}-\mathrm{j}}$ & $17.3^{f-n}$ & $19.8^{\mathrm{g}-\mathrm{k}}$ & $25.7^{c-e}$ & $18^{g-m}$ & $26^{c-e}$ \\
\hline Chicken Manure & $34.2^{b-h}$ & $33^{d-j}$ & $34.2^{\mathrm{b}-\mathrm{h}}$ & 33.1 & $31^{\mathrm{j}-\mathrm{n}}$ & $26^{g-k}$ & $14.8^{\mathrm{m}-\mathrm{o}}$ & $25.7^{c-e}$ & $17^{\mathrm{j}-\mathrm{o}}$ & $29^{c}$ \\
\hline Control & $33.5^{c-i}$ & $33^{c-j}$ & $28.7^{\circ}$ & 31.4 & $33^{e-j}$ & $22^{\mathrm{e}-\mathrm{i}}$ & $17.6^{\mathrm{i}-\mathrm{n}}$ & $25^{c-f}$ & $17^{\mathrm{j}-\mathrm{o}}$ & $19^{g-h}$ \\
\hline Main B & 35.5 & 33.2 & 32.6 & 32.4 & 32.3 & 27.6 & 17.3 & 24.9 & 20 & 24 \\
\hline
\end{tabular}


Table 9. Cont.

\begin{tabular}{|c|c|c|c|c|c|c|c|c|c|c|}
\hline \multirow[t]{2}{*}{ Treatments } & \multicolumn{5}{|c|}{$\begin{array}{l}\text { Nitrogen Content } \\
\text { Ecotype }(\mathrm{mg} / \mathrm{g})\end{array}$} & \multicolumn{5}{|c|}{$\begin{array}{l}\text { Essential Oil } \\
\text { Ecotype }\end{array}$} \\
\hline & Qaziantep & Hamadan & Urmia & Yazd & Shiraz & Qaziantep & Hamadan & Urmia & Yazd & Shiraz \\
\hline \multicolumn{11}{|c|}{2015} \\
\hline Nano Nitrogen & $33.6^{h-p}$ & $26.6^{\mathrm{o}-\mathrm{s}}$ & $25.1^{\mathrm{q}-\mathrm{s}}$ & $28.6^{\mathrm{m}-\mathrm{s}}$ & $30^{k-r}$ & $16^{\mathrm{h}-\mathrm{o}}$ & $12.33^{n-o}$ & $18^{\mathrm{h}-\mathrm{n}}$ & $20^{g-k}$ & $20^{g-k}$ \\
\hline Magnetic Water & $30.7^{\mathrm{j}-\mathrm{r}}$ & $38.5^{e-j}$ & $26.9^{n-s}$ & $27.2^{n-s}$ & $29^{1-s}$ & $12.3^{\mathrm{a}}$ & $17.3^{\mathrm{i}-\mathrm{n}}$ & $19.3^{\mathrm{g}-\mathrm{l}}$ & $19^{g-1}$ & $17^{\mathrm{i}-\mathrm{n}}$ \\
\hline Urea & $29.7^{\mathrm{k}-\mathrm{r}}$ & $32.8^{\mathrm{i}-\mathrm{q}}$ & $26.7^{\mathrm{n}-\mathrm{s}}$ & $35.4 \mathrm{hm}$ & $24.8^{\mathrm{rs}}$ & $17.8^{\mathrm{h}-\mathrm{n}}$ & $16.7^{j-p}$ & $18^{\mathrm{h}-\mathrm{n}}$ & $23^{d-g}$ & $17^{\mathrm{i}-\mathrm{n}}$ \\
\hline Chicken Manure & $34.1^{\mathrm{h}-\mathrm{o}}$ & $30.3^{\mathrm{k}-\mathrm{r}}$ & $34.1^{\mathrm{h}-\mathrm{o}}$ & $25.1^{\mathrm{q}-\mathrm{s}}$ & $21.3^{s}$ & $16.3^{\mathrm{j}-\mathrm{o}}$ & $13.3^{n-o}$ & $16^{\mathrm{k}-\mathrm{o}}$ & $16^{\mathrm{k}-\mathrm{o}}$ & $19^{g-h}$ \\
\hline Control & $26.9^{n-s}$ & $25.9^{\mathrm{p}-\mathrm{s}}$ & $26.9^{\mathrm{n}-\mathrm{s}}$ & $21.8^{\mathrm{s}}$ & $25.2^{q-s}$ & $17.3^{\mathrm{i}-\mathrm{n}}$ & $12.3^{\mathrm{p}}$ & $22.3^{\mathrm{e}-\mathrm{h}}$ & $16^{\mathrm{k}-\mathrm{o}}$ & $19^{g-h}$ \\
\hline Main B & 31 & 30.8 & 27.9 & 27.6 & 26 & 15.9 & 14.4 & 18.7 & 18.8 & 18.4 \\
\hline
\end{tabular}

Similar letters above the values show non-significant difference at $p<0.05$ by Duncan test.

\subsection{The N Content of Fennel Fruits}

The foliar application of the organic fertilizer, inorganic fertilizer, and magnetic water brought about significant differences in the $\mathrm{N}$ content of fennels (Table 9). The magnetic water increased the seed $\mathrm{N}$ content significantly versus the other solutions in both years. The highest $\mathrm{N}$ content of $39 \mathrm{mg} / \mathrm{g}$ was related to Ghazian tep treated with magnetic water in the first year, and the lowest of $21.3 \mathrm{~kg} / \mathrm{ha}$ was related to the Shiraz landrace treated with chicken manure in the second year (Table 9). The increase in $\mathrm{N}$ under the magnetic water treatment can be related to the hydrogen bonds of water molecules, which are severely influenced by the magnetic field such that solubility increases. In addition, the magnetic field affected the cell membrane permeability of fava beans and changed the ion movement of the membrane [83]. Since magnetic water has different physical characteristics from conventional water, it has a higher capacity for the dissolution of salt and minerals [84]. Esitken and Turan [85] observed that the magnetic field increased the $\mathrm{N}$ content of strawberry leaves. The effectiveness of magnetic water varies with plant organs [86] and species [87]. The accumulation of ions positively affects plant growth and production, and magnetic fields play a key role in increasing the uptake capacity of ions and non-fluid ions.

Ions and nutrients are made directional by the magnetic field treatment. This phenomenon is similar to the effect of magnetic fields on solid objects. This changes the uptake rate, and obviously, plants that absorb more nutrients exhibit a higher rate of growth and higher yields [88]. Influenced by an external magnetic field, the energy of paramagnetic materials in plants, which is transported by free electrons, increases, resulting in the activation of plant hormones [80]. This finding is supported by the reports of Nasreen et al. [89] and El Sagan and Baset [90] about onion and Darzi [91] about parsley. The N content of pear seedlings and tomato seedlings irrigated with magnetic water was higher than conventional water [58,91]. Mohsen and Kassem [82] reported that magnetic water increased the $\mathrm{N}$ content of fennel fruits.

\subsection{The P Content of Fennel Fruits}

Based on the results of two-year combined variance analysis of the data, the interactive effect of the three factors was significant such that the maximum $P$ content of $8.7 \mathrm{mg} / \mathrm{g}$ was obtained from Ghaziantep treated with the magnetic water in the first year and the minimum one of $4.1 \mathrm{mg} / \mathrm{g}$ from the Shiraz landrace treated with the magnetic water in the second year (Table 10). Magnetic water changes soil's physical and chemical characteristics, increasing nutrient availability to plants [92]. Furthermore, it affects plant hormones, thereby increasing cell activity and improving plant growth [64]. The irrigation of pear and tomato seedlings with magnetic water increased their $\mathrm{N}$ content versus the application of conventional water $[50,83]$. In a study on chickpea and cowpea, Maheshwari and Grewal [64] reported the favorable effect of magnetic water on plant minerals. Mohsen and Kassem [82] reported similar results about the increased content of $P$ in the seeds of fennel plants that were treated with magnetic water. 
Table 10. The effect of different sources of fertilizer and magnetic water on potassium and phosphor contents of sweet fennel plants in the 2014-2015 and 2015-2016 cropping years.

\begin{tabular}{|c|c|c|c|c|c|c|c|c|c|c|}
\hline \multirow[t]{2}{*}{ Treatments } & \multicolumn{5}{|c|}{$\begin{array}{c}\text { Potassium } \\
\text { Ecotype }(\mathrm{mg} / \mathrm{g})\end{array}$} & \multicolumn{5}{|c|}{$\begin{array}{c}\text { Phosphor } \\
\text { Ecotype (mg/g) }\end{array}$} \\
\hline & Qaziantep & Hamadan & Urmia & Yazd & Shiraz & Qaziantep & Hamadan & Urmia & Yazd & Shiraz \\
\hline \multicolumn{11}{|c|}{2014} \\
\hline Nano Nitrogen & $27.8^{a}$ & $18.8^{\mathrm{h}-1}$ & $17.4^{1-r}$ & $16.8^{\mathrm{n}-\mathrm{t}}$ & $17^{\mathrm{o}-\mathrm{t}}$ & $7.7^{a b}$ & $7.8^{\mathrm{a}}$ & $5.8^{\mathrm{h}-\mathrm{O}}$ & $5.1^{\mathrm{n}-\mathrm{t}}$ & $5.7^{g-q}$ \\
\hline Magnetic Water & $28.5^{\mathrm{a}}$ & $19.2^{g-j}$ & $12 \mathrm{ef}$ & $19.2 \mathrm{gk}$ & $19.4^{g-j}$ & $8.7^{\mathrm{j}-\mathrm{q}}$ & $6.6^{c-g}$ & 7 bcd & $5.6^{\mathrm{d}-\mathrm{h}}$ & $5.4^{\mathrm{m}-\mathrm{t}}$ \\
\hline Urea & $15.2^{t-w}$ & $19.4^{\mathrm{g}-\mathrm{j}}$ & $20^{\mathrm{fh}}$ & $16.2^{\mathrm{q}-\mathrm{u}}$ & $18.5^{\mathrm{h}-1}$ & $6.5^{c-i}$ & $5.4^{\mathrm{m}-\mathrm{t}}$ & $6^{g-m}$ & $5.3^{\mathrm{n}-\mathrm{t}}$ & $5.4^{\mathrm{m}-\mathrm{t}}$ \\
\hline Chicken Manure & 22.4 de & $17.4^{1-\mathrm{k}}$ & $14.5^{\mathrm{vw}}$ & $17.2^{1-\mathrm{s}}$ & $18.4^{i-n}$ & $4.3^{\mathrm{abc}}$ & $5.2^{\mathrm{o}-\mathrm{t}}$ & $6.2^{\mathrm{f}-\mathrm{k}}$ & $6.5^{\mathrm{d}-\mathrm{h}}$ & $5.5^{1-\mathrm{s}}$ \\
\hline Control & $17.8^{\mathrm{j}-\mathrm{o}}$ & $17.2^{1-\mathrm{s}}$ & $15.8^{\mathrm{p}-\mathrm{u}}$ & $18.3^{\mathrm{j}-\mathrm{n}}$ & $18^{\mathrm{j}-\mathrm{o}}$ & $4.7^{\mathrm{t}-\mathrm{v}}$ & $5.4^{\mathrm{m}-\mathrm{t}}$ & $4.9^{\mathrm{r}-\mathrm{h}}$ & $6.7^{\mathrm{l}-\mathrm{s}}$ & $6.6^{c-g}$ \\
\hline Main B & 22.34 & 18.4 & 15.9 & 17.54 & 18.24 & 6.38 & 6.1 & 5.98 & 5.84 & 5.72 \\
\hline \multicolumn{11}{|c|}{2015} \\
\hline Nano Nitrogen & $18^{\mathrm{h}-\mathrm{o}}$ & $16.8^{\mathrm{m}-\mathrm{t}}$ & $18.1^{\mathrm{h}-\mathrm{m}}$ & $16.3^{\mathrm{p}-\mathrm{u}}$ & $19.4^{g-j}$ & $5.9^{\mathrm{h}-\mathrm{n}}$ & $6.9^{\mathrm{b}-\mathrm{e}}$ & $5.9^{\mathrm{h}-\mathrm{n}}$ & $5.7^{\mathrm{k}-\mathrm{r}}$ & $4.9^{\mathrm{s}-\mathrm{u}}$ \\
\hline Magnetic Water & $15^{q-u}$ & $15^{\mathrm{q}-\mathrm{u}}$ & $17.9^{\mathrm{j}-\mathrm{p}}$ & $17.4^{1-r}$ & $19.5^{\mathrm{f}-\mathrm{g}}$ & $7.4^{\mathrm{ab}}$ & $5.1^{\mathrm{g}-\mathrm{u}}$ & $6.5^{\mathrm{d}-\mathrm{i}}$ & $5.1^{\mathrm{p}-\mathrm{u}}$ & $4.1^{\mathrm{u}-\mathrm{v}}$ \\
\hline Urea & $17.8^{\mathrm{j}-\mathrm{o}}$ & $17.8^{\mathrm{j}-\mathrm{o}}$ & $14.2^{\mathrm{s}-\mathrm{u}}$ & $18^{\mathrm{j}-\mathrm{o}}$ & $19.9^{\mathrm{f}-\mathrm{i}}$ & $6.6^{c-g}$ & $4^{\mathrm{v}}$ & $6.3^{\mathrm{e}-\mathrm{j}}$ & $4.5^{\mathrm{u}-\mathrm{v}}$ & $5.7^{\mathrm{j}-\mathrm{q}}$ \\
\hline Chicken Manure & $14.6^{\mathrm{vw}}$ & $14.6^{\mathrm{vw}}$ & $20.5^{f-g}$ & $14.1^{\mathrm{w}}$ & $20^{\mathrm{fh}}$ & $5.8^{\mathrm{i}-\mathrm{p}}$ & $4.7^{\mathrm{t}-\mathrm{v}}$ & $6.9^{b-f}$ & $5.7^{\mathrm{j}-\mathrm{g}}$ & $7.3^{\mathrm{abc}}$ \\
\hline Control & $15.8^{\mathrm{o}-\mathrm{r}}$ & $15.8^{\mathrm{p}-\mathrm{u}}$ & $14.4^{\mathrm{VW}}$ & $15.7^{\mathrm{o}-\mathrm{r}}$ & $15.5^{\mathrm{p}-\mathrm{u}}$ & $5.4^{\mathrm{m}-\mathrm{s}}$ & $6.1^{\mathrm{g}-1}$ & $7^{b-d}$ & $5.6^{\mathrm{k}-\mathrm{r}}$ & $4.5^{\mathrm{w}}$ \\
\hline Main B & 16.22 & 16 & 17.02 & 16.3 & 18.86 & 6.22 & 5.36 & 6.52 & 5.32 & 5.3 \\
\hline
\end{tabular}

Same letters above numbers show non-significant difference at $p<0.05$ by Duncan test.

\subsection{The K Content of Fennel Fruits}

The comparison of the two-year means revealed that the interaction of the three factors was significant on this trait. The Ghaziantep plants treated with magnetic water in the first year exhibited the highest K content of $28.5 \mathrm{mg} / \mathrm{g}$ and the Yazd plants treated with chicken manure in the second year exhibited the lowest one of $14.1 \mathrm{mg} / \mathrm{g}$ (Table 10). Magnetic fields make cell membranes permeable and change ion movements across the membrane [93]. This, eventually, increases osmotic pressure. The osmotic pressure of the cell membrane reaches a balance with an increase in $\mathrm{K}$ content and an increase in the $\mathrm{K} / \mathrm{Na}$ ratio [94]. Researchers suggest that the accumulation of some minerals, e.g., $\mathrm{K}$, in plants contributes to preserving cell turgor and improving the morphological and physiological traits of plants by preventing the degradation of cell walls against reactive oxygen species, increasing the activity of antioxidant enzymes, and increasing water use efficiency [95]. Esitken and Turan [85] showed that the magnetic field increased the $\mathrm{K}$ ion content of strawberries. The positive effect of magnetic water was reported on the K content of plants $[57,66,82,96-98]$ for basil, faba, fennels, chickpea, and periwinkle. Hasan et al. [99] reported that applying magnetic water solution increased $\mathrm{K}$ uptake by increasing the $\mathrm{K} / \mathrm{Na}$ ratio.

\subsection{Essential Oil Composition}

The comparison of the means indicated that the foliar application influenced essential oil composition significantly. The highest p-anisaldehyde, limonene, and alpha-pinene contents $(3.28 \%, 4.41 \%$, and $0.58 \%$, respectively) were observed in the landraces treated with the magnetic water, and the highest anethole and fenchone contents $(80.16 \%$ and $7.92 \%$, respectively) were observed in the landraces treated with the chicken manure (Table 11). The highest alpha-pinene, beta-mercine, $\mathrm{p}$-simene and beta-osimene contents $(0.58 \%, 0.13 \%, 0.35 \%$ and $0.27 \%$, respectively) were observed in the landraces treated with the magnetic water.

Abdul-Jaleel et al. [100] state that the concentration of secondary compounds in plants depends on environmental factors, such as nutrients and light, which influence plant yields and the quantity and quality of compounds. The main constituents of fennel include anethole, fenchone, limonene, estragole, and anise aldehyde. Darzi et al. [101] state that the high anethole content of fennel's essential oil improves its quality. Since the essential oil is a terpenoid compound whose constituents urgently need ATP and the presence of such elements as nitrogen is necessary [89], $\mathrm{N}$ availability increases anethole content and decreases estragole content. Jamshidi et al. [20] observed that applying chemical and 
organic fertilizers increased anethole, fenchone, and limonene contents in fennels. The fenchone content was higher in most foliar application treatments than in the control treatment. Younesian et al. [102] revealed that the anethole percentage of fennel was higher than the other compounds and was affected by the fertilization treatments such that manure was most influential on anethole content. Based on the percentages, the Urmia landrace had the highest anethole percentage $(83.18 \%)$, and the Shiraz landrace had the lowest one (77.52\%) (Table 12). Baydar et al. [103] and Bettaieb et al. [104] argue that medicinal herbs ${ }^{\prime}$ essential oil yield and quality depend on genotype, but they are influenced by climatic factors, soil physical and chemical conditions, and available nutrients. Some researchers also suggest that the quality of essential oil constituents is mainly affected by genotype, but environmental factors are less influential [105].

Table 11. The effect of different sources of fertilizer and magnetic water on the essential oil of fennel in the 2014-2015 and 2015-2016 cropping years.

\begin{tabular}{lccccc}
\hline & \multicolumn{5}{c}{ Foliar Application } \\
\cline { 2 - 6 } & Control & Chicken Manure & Urea & Magnetic Water & Nano-N \\
\hline Trans-anetol & 79.2 & 80.16 & 78.9 & 78.98 & 81.21 \\
Fenchone & 7.32 & 7.92 & 6.89 & 7.37 & 7.56 \\
Limonene & 3.98 & 3.94 & 4.11 & 4.41 & 3.45 \\
Estragol & 4.21 & 4.67 & 4.52 & 4.96 & 4.68 \\
P-anisaldehyde & 2.35 & 2.77 & 2.76 & 3.28 & 2.96 \\
Alpha-pinene & 0.48 & 0.48 & 0.48 & 0.58 & 0.44 \\
Sabinene & 0.08 & 0.08 & 0.14 & 0.11 & 0.11 \\
Beta-mercine & 0.1 & 0.09 & 0.12 & 0.13 & 0.08 \\
p-simene & 0.09 & 0.11 & 0.1 & 0.35 & 0.1 \\
1.8 Cineol & 0.15 & 0.22 & 0.16 & 0.2 & 0.18 \\
Camphor & 0.07 & 0.1 & 0.07 & 0.1 & 0.12 \\
Beta-osimene & 0.24 & 0.25 & 0.22 & 0.27 & 0.22 \\
Camphen & 0.01 & 0.01 & - & - & - \\
L-phelendrel & 0.01 & - & - & - & - \\
\hline
\end{tabular}

Table 12. The essential oil of some fennel landraces in the 2014-2015 and 2015-2016 cropping years.

\begin{tabular}{lccccc}
\hline & \multicolumn{5}{c}{ Landrace } \\
\cline { 2 - 6 } & Shiraz & Yazd & Urmia & Hamadan & Qazian Tep \\
\hline Trans-anetol & 77.52 & 80.82 & 83.18 & 78.68 & 78.04 \\
Fenchone & 8.75 & 9.61 & 2.18 & 8.58 & 8.53 \\
Limonene & 3.93 & 3.85 & 4.2 & 3.96 & 4.18 \\
Estragol & 5.27 & 4.31 & 5.27 & 3.87 & 4.18 \\
P-anisaldehyde & 3.04 & 3.25 & 2.91 & 2.12 & 2.61 \\
Alpha-pinene & 0.54 & 0.46 & 0.33 & 0.53 & 0.6 \\
Sabinene & 0.12 & 0.1 & 0.11 & 0.06 & 0.11 \\
Beta-mercine & 0.14 & 0.09 & 0.01 & 0.14 & 0.12 \\
P-simene & 0.09 & 0.09 & 0.15 & 0.05 & 0.08 \\
1.8 Cineol & 0.21 & 0.17 & 0.16 & 0.15 & 0.12 \\
Camphor & 0.12 & 0.09 & 0.01 & 0.15 & 0.12 \\
Beta-osimene & 0.26 & 0.27 & 0.27 & 0.27 & 0.14 \\
Camphen & 0.01 & 0.01 & - & - & - \\
L-phelendrel & - & - & - & - & 0.01 \\
\hline
\end{tabular}

Limonene percentage was lower in the treatments that had a higher anethole percentage. Most research studies have reported that applying organic and chemical fertilizers increases some compounds and decreases others [20,44,106-108]. 


\section{Conclusions}

The results showed that optimal yields could be obtained by identifying plant cultivars and through proper nutritional regimes. One of the influential factors was the foliar application of magnetic water, which had the greatest impact on morphological and physiological traits. Magnetic water improved plant growth by increasing nutrient solubility. The Ghaziantep landrace had the highest seed yield, biological yield, chlorophyll $a$ and $b$ contents, and N, P, and K contents. The Urmia landrace had the highest mean essential oil yield of both years treated with manure. Organic fertilizers improved plant growth and quality due to their effect on the availability of most micronutrients and macronutrients compared to chemical fertilizers. Furthermore, the Urmia landrace had the highest anethole percentage. In another study, it seems necessary to compare the Urmia landrace with the Ghaziantep landrace in the same or different treatment conditions to select the better one for sustainable production of medicinal plants and the replacement of chemical inputs.

Author Contributions: Methodology, formal analysis and writing; S.F., Formal analysis; M.T., Conceptualization, Supervision and project administration; R.A., Writing-Review and editing H.A.E.E. and R.Z.S. All authors have read and agreed to the published version of the manuscript.

Funding: This work was funded by Research Management Center (RMC), Universiti Teknologi Malaysia (UTM), through grant No. R.J130000.7344.4C240 and R.J130000.7609.4C359.

Institutional Review Board Statement: Not applicable.

Informed Consent Statement: Not applicable.

Data Availability Statement: All the data is available in the manuscript file.

Acknowledgments: We would like to thank Karel Innemie from Leiden University (The Netherlands), head of the Dutch archaeological mission at Wadi El-Natrun, who provided us data and some of the figures inserted in this study.

Conflicts of Interest: All the authors declare no conflict of interest.

\section{References}

1. Rezaei Chiyaneh, E.; Zehtab Salmasi, S.; Ghassemi Golezani, K.; Delazar, A. Physiological responses of Fennel (Foeniculum vulgare L.) to water limitation. J. Agroecol. 2012, 4, 347-355. (In Persian)

2. Telci, İ.; Demirtaş, İ.; Şahin, A. Variation in plant properties and essential oil composition of sweet fennel (Foeniculum vulgare Mill.) fruits during stages of maturity. Ind. Crop. Prod. 2009, 30, 126-130. [CrossRef]

3. Marino, S.D.; Gala, F.; Borbone, N.; Zollo, F.; Vitalini, S.; Visioli, F.; Iorizzi, M. Phenolic glycosides from Foeniculum vulgare fruit and evaluation of the antioxidative activity. Phytochemistry 2007, 68, 1805-1812. [CrossRef]

4. Anant, K.J.; Sanket, K.J.; Tarun, P. Seed Album of Some Medicinal Plants of India; Asian Medicinal Plants and Health Care Trust: New Delhi, India, 2005.

5. Chaudhary, S.K.; Maity, N.; Nema, N.K.; Bhadra, S.; Saha, B.P.; Mukherjee, P.K. Angiotensin converting enzyme inhibition activity of fennel and coriander oils from India. Nat. Prod. Commun. 2010, 8, 671-672. [CrossRef]

6. Bahmani, K.; Izadi Darbandi, A.; Sadat Noori, S.A. Evaluation of essential oil content and components in some Iranian Fennel ecotypes. Agric. Crop. Manag. 2013, 15, 129-135. (In Persian)

7. Nikbakht, J.; Rezaee, E. Effect of different levels of magnetized wastewater on yield and water use efficiency in Maize and some of soil physical properties. Soil Water Res. 2017, 48, 63-75. (In Persian)

8. Kahrizi, D.; Cheghamirza, K.; Akbari, L.; Rostami-Ahmadvandi, H. Effects of magnetic field on cell dedifferentiation and callus induction derived from embryo culture in bread wheat (Triticum aestivum L.) genotypes. Mol. Biol. Rep. 2013, 40, 1651-1654. [CrossRef]

9. Radhakrishnan, R.; Kumari, B.D.R. Influence of pulsed magnetic field on soybean (Glycine max L.) seed germination, seedling growth and soil microbial population. Indian J. Biochem. Biophys. 2013, 50, 312-317. [PubMed]

10. Alemánm, E.I.; Nbogholi, A.; Boix, Y.F.; González-Olmedo, J.; Chalfun-Junior, A. Effects of EMFs on some biological parameters in coffee plants (Coffea arabica L.) obtained by in vitro propagation. Pol. J. Environ. Stud. 2014, 23, 95-101.

11. Yan, D.; Guo, Y.; Zai, X.; Qin, P. Effects of electromagnetic fields exposure on rapid micropropagation of beach plum (Prunus martima). Ecol. Eng. 2009, 35, 597-601.

12. Tanaka, M.; Van, P.T.; Teixeira da Silva, J.A.; Ham, L.H. Novel magnetic field system: Application to micropropagation of horticultural plants. Biotech. Biotechnol. Equip. 2010, 24, 2160-2163. [CrossRef] 
13. Çelik, O.; Atak, Ç.; Rzakulieva, A. Stimulation of rapid regeneration by a magnetic field in Paulownia node cultures. J. Cent. Eur. Agric. 2008, 9, 297-304.

14. Jaime, A.; Silva, T.D.; Dobránszki, J. Impact of magnetic water on plant growth. Environ. Exp. Bot. 2014, 12, 137-142.

15. Ghadami Firozabadi, A.; Khoshravesh, M.; Shirazi, P.; Zarea Byane, H. Effect of Irrigation with Magnetized Water on the Yield and Biomass of Soybean var. DPX under water deficit and salinity stress. J. Water Res. Agric. 2016, 30, 131-143. (In Persian)

16. Abdul Qados, A.M.S.; Hozayn, M. Response of growth, yield, yield components and some chemical constituents of flax for irrigation with magnetized and tap water. World Appl. Sci. J. 2010, 8, 630-634.

17. Mahmoud, H.; Amira, M.S. Magnetic water application for improving wheat (Triticum aestivum L.) crop production. Agric. Biol. J. N. Am. 2010, 1, 677-682.

18. El Sayed, H.A.S. Impact of magnetic water irrigation improves the growth, chemical composition, and yield production of Broad Bean (Vicia faba L.). Am. J. Exp. Agric. 2014, 4, 476-496.

19. Moradi, R.; Rezvani Moghaddam, P.; Nasiri Mahallati, M.; Nezhadali, A. Effects of organic and biological fertilizers on fruit yield and essential oil of sweet fennel (Foeniculum vulgare var. dulce). Span. J. Agric. Res. 2011, 9, 546-553. [CrossRef]

20. Jamshidi, E.; Ghalavand, A.; Sefidkon, F.; Mohammadi Goltapeh, E. Effect of different nutrition systems (organic and chemical) on quantities and qualities characteristics of Fennel (Foeniculum Vulgare Mill) under water deficit stress. Iran. J. Med. Aromat. Plants 2012, 28, 309-323.

21. Dahmardeh, M.; Dahmardeh, M.; Khammari, E.; Gorgich, P. The effects of Animal manures and nitrogen fertilizer on quantity and the quality yield on a variety of RGS003 on Autumnal Canola (Brassica napus). Trakia J. Sci. 2010, 1, 42-44.

22. Picard, D.; Ghiloufi, M.; Saulas, P.; Devx Tourdonnet, S. Does under sowing winter wheat with a cover crop increase competition for resources, and is it compatible with high yield? Field Crop. Res. 2010, 115, 9-18. [CrossRef]

23. Mehnaz, S.; Lazarovits, G. Inoculation effects of Pseudomonas putida, Gluconacetobacter azotocaptans, and Azospirillum lipoferum on corn plant growth under greenhouse conditions. Microbial. Ecol. 2006, 51, 326-335. [CrossRef] [PubMed]

24. Neisani, S.; Fallah, S.; Raiesi, F. The effect of poultry manure and urea on agronomic characters of forage Maize under drought stress conditions. J. Agric. Sci. Sustain. Prod. 2011, 2, 63-74. (In Persian)

25. Azzaz, N.A.; Hassan, E.A.; Hamad, E.H. The Chemical Constituent and Vegetative and Yielding Characteristics of Fennel Plants Treated with Organic and Bio-fertilizer Instead of Mineral Fertilizer. Aust. J. Basic Appl. Sci. 2009, 3, 579-587.

26. Ahmed, A. Effect of mineral and organic fertilizers on Roselle's growth and calyx yield (Hibiscus sabdariffa L.). Int. J. Manures Fertil. 2013, 2, 434-436.

27. Bistgani, Z.E.; Siadat, S.A.; Bakhshandeh, A.; Pirbalouti, A.G.; Hashemi, M.; Maggi, F.; Morshedloo, M.R. Application of combined fertilizers improves biomass, essential oil yield, aroma profile, and antioxidant properties of Thymus daenensis Celak. Ind. Crop. Prod. 2018, 121, 434-440. [CrossRef]

28. Golestaneh, S.; Ganjali, H.R.; Khamari, I.; Mehraban, A. Morphological Features Response of Calendula to the Application of Animal Manures (Cow, Chicken and Ostrich Manures). Int. J. Agric. Innov. Res. 2013, 2, 341-345.

29. Rezvani Moghaddam, P.; Norouzian, A.; Seyyedi, S.M. Evaluation of the effects of manure and mycorrhizal inoculation on grain and oil yield of spring Sunflower cultivars (Carthamus tinctorius L.). J. Agroecol. 2015, 7, 331-343. (In Persian)

30. Al-Enzy, A.F.M.; Ziydan, B.A.; Almehemdi, A.F. Effect of adding two types of Organic fertilizers in some growth and yield indicators for two cultivars of Fennel (Foeniculum Vulgare mill.). Plant. Arch. 2019, 19, 4143-4148.

31. Abbas, I.S.; Abdul Muttalib, A.G.N. The response of sweet fennel plant (Foeniculum-vulgare Mill) to field practices and their effects on growth characters' crop yield and the active constituents of the fruits. J. Kerbala Univ. 2011, 9, 117-125.

32. Bekhrad, H.; Nikonam, F.; Mahdavi, B. Effects of nano-fertilizer and different levels of nitrogen on grain and oil yield of Sesame. J. Plant. EcoPhysiol. 2017, 9, 110-122. (In Persian)

33. Kole, C.; Kole, P.; Randunu, K.M.; Choudhary, P.; Podila, R.; Ke, P.C.; Rao, A.M.; Marcus, R.K. Nanobiotechnology can boost crop production and quality: First evidence from increased plant biomass, fruit yield and phytomedicine content in bitter melon (Momordica charantia). BMC Biotechnol. 2013, 13, 37. [CrossRef] [PubMed]

34. Abdelkader, M.A.I.; Fatma, R.; Ibrahim, F.R.; Metwaly, E.E. Growth and Productivity of Fennel (Foeniculum vulgare, Mill) Plants as Affected by Phosphorus Rate and Nano-Micronutrients Concentration. J. Plant. Prod. Mansoura Univ. 2019, 10, 483-488. [CrossRef]

35. Naderi, M.R.; Danesh-Shahraki, A. Nano-fertilizers and their roles in sustainable agriculture. Int. J. Agric. Crop Sci. 2013, 5, 2229-2232.

36. Heidarzadeh, N.; Mohamadpour, H. The effect of magnetic field on scale deposition of Birjand tap water. Iran. Water Resour. Res. 2017, 13, 198-204. (In Persian)

37. Feizi Asl, V.; Valizadeh, G.H.R. Effect of urea liquid fertilizer spraying at different plant growth stages on grain quality and quantity in sardari dryland wheat (Triticum. aestivum. L.). Iran. J. Agric. Sci. 2004, 35, 301-311. (In Persian)

38. Ghorbani, R.; Koochaki, A.; Asadi, G.; Jahan, M. Effect of organic amendments and compost extracts on tomato production and storability in ecological production systems. Field Crop. Res. 2008, 6, 111-116. (In Persian)

39. Clevenger, J.F. Apparatus for determination of essential oil. J. Am. Pharm. Assoc. 1928, 17, 346-349.

40. Arnon, D.T. Copper enzymes in isolated chloroplasts polyphenol oxidase in Beta vulgaris. Plant. Physiol. 1949, 24, 1-15. [CrossRef]

41. Pregl, F. Quantitative Organic Microanalysis, 4th ed.; J. A. Churchill. Ltd.: London, UK, 1945. 
42. Rawe, G.J. Food-Analysis by Atomic Absorption Spectroscopy; Varian Techtron: Belrose, Australia; Palo Alto, CA, USA; Steinhausen, Switzerland, 1973; p. 89.

43. King, E.J. Micro-Analysis in Medical Biochemistry, 2nd ed.; Churchill Publishing Co.: London, UK, 1951.

44. Adams, R.P. Identification of Essential Oil Components by Gas Chromatography/Mass Spectrometry; Allured Publishing Corporation: Carol Stream, IL, USA, 2007; Volume 456.

45. AmaniMachiani, M.; Javanmard, A.; Morshedloo, M.R.; Maggi, F. Evaluation of yield, essential oil content and compositionsof peppermint (Menthapiperita L.) intercropped withfaba bean (Viciafaba L.). J. Clean. Prod. 2018, 171, 529-537. [CrossRef]

46. Morshedloo, M.R.; Craker, L.E.; Salami, A.; Nazeri, V.; Sang, H.; Maggi, F. Effect of prolonged water stress on essentialoil content, compositions and gene expression patterns ofmono-andsesquiterpene synthesis in two oregano (Origanumvulgare L.) subspecies. Plant Physiol. Biochem. 2017, 111, 119-128. [CrossRef] [PubMed]

47. Mohamed, M.A.H.; Abdu, M. Growth and Oil Production of Fennel (Foeniculum vulgare Mill): Effect of Irrigation and Organic Fertilization. Biol. Agric. Hortic. 2004, 22, 31-39. [CrossRef]

48. Arisha, H.M.E.; Gad, A.A.; Younes, S.E. esponse of some pepper cultivars to organic and mineral nitrogen fertilizers under sandy soil conditions. Zagazig J. Agric. Res. 2003, 30, 1875-1899.

49. Zhou, D.M.; Hao, X.Z.; Wang, Y.J.; Dong, Y.H.; Cang, L. Copper and Zn uptake by radish and pakchoi as affected by application of livestock and poultry manures. Chemosphere 2005, 59, 167-175. [CrossRef]

50. Sanni, K.O. Effect of compost, cow dung, and NPK15-15-15 fertilizer on growth and yield performance of Amaranth (Amaranthus hybridus). Int. J. Adv. Sci. Res. 2016, 2, 76-82. [CrossRef]

51. Emami Bistgani, Z.; Siadat, S.A.; Bakhshandeh, A.; GhasemiPirbaluti, A.; Hashemi, M. Influence of chitosan concentration on morpho-physiological traits, essential oil and phenolic content under different fertilizers application in Thymus daenensis. $J$. Med. Herb. 2016, 7, 117-125.

52. Eisa, E.A. Effect of Some Different Sourses of Organic Fertilizers and Seaweed Extract on Growth and Essential Oil of Sweet Fennel (Foeniculum vulgare Mill.) Plants. J. Plant. Prod. 2016, 7, 575-584. [CrossRef]

53. Ali, A.F.; Hassan, E.A.; Hamad, E.H.; Abo-Quta, W.M.H. Effect of compost, ascorbic acid and salicylic acid treatments on growth, yield and oil production of fennel plant. Assiut J. Agric. Sci. 2017, 48, 139-154.

54. Shabrangi, A.; Majd, A. Effect of magnetic fields on growth and antioxidant systems in agricultural plants. PIERS Proc. Beijing China 2009, 23-27, 1142-1147.

55. Olowoake, A.A.; Adeoye, G.O. Influence of differently composted organic residues on the yield of maize and its residual effects on the fertility of an Alfisol in Ibadan, Nigeria. Int. J. Agric. Environ. Biotech. 2013, 6, 79-84.

56. Reyhan, M.K. Amisalani, studying the relationship between the vegetation and physicochemical properties of soil: Case study, Tabas region, Iran. Pak. J. Nutr. 2006, 5, 169-171.

57. Souad, A.E.; Mohammed, A.M.; Mohammed, S.K.; Yasser, A.H.O.; El-Sayed, E. Effect of magnetite Nano-fertilizer on growth and yield of Ocimum basilicum L. Int. J. Indig. Med. Plants 2013, 46, 1286-1293.

58. Ahmed, Y.M.; Shalaby, E.A.; Shanan, N.T. Organic and inorganic cultures improve vegetative growth, yield characters, and antioxidant activity of Roselle plants (Hibiscus sabdariffa L.). Afr. J. Biotechnol. 2011, 10, 1988-1996.

59. Taha, B.A.; Khalil, A.E.; Ashraf, M.K. Magnetic treatments of Copsicum Annuum, L. Grown under saline irrigation conditions. J. Appl. Sci. Res. 2011, 7, 1558-1568.

60. Babaloo, F.; Majd, A.; Arbabian, S.; Sharifnia, F.; Ghanati, F. The Effect of Magnetized Water on Some Characteristics of Growth and Chemical Constituent in Rice (Oryza sativa L.) Var Hashemi. Eurasian J. Biosci. 2018, 12, 129-137.

61. Marghabeizadeh, G.; Gharineh, M.H.; Fathi, G.H.; Abdali, A.R.; Farbod, M. Effect of ultrasound waves and magnetic field on germination, growth, and yield of Carumcopticum (L.) C. B. Clarke in lab and field conditions. J. Med. Aromat. Plants 2015, 30, 539-560. (In Persian)

62. Safaei, L.; Afiuni, D.; Zeinali, H. Correlation relationships and path coefficient analysis between essential oil and essential oil components in 12 genotypes of Fennel (Foeniculum vulgare Mill.). J. Med. Aromat. Plants 2013, 29, 187-200. (In Persian)

63. Ehsanipour, A.; Razmjoo, K.; Zeinali, H. Effect of nitrogen rates on yield, yield components and essential oil content of several Fennel (Foeniculum vulgare Mill.) populations. J. Med. Aromat. Plants 2013, 28, 579-593. (In Persian)

64. Maheshwari, B.L.; Grewal, H.S. Magnetic treatment of irrigation water: Its effects on vegetable crop yield and water productivity. Agric. Water. Manag. 2009, 96, 1229-1236. [CrossRef]

65. Kargarshooraki, E.; Majd, A. The comparative study of the effects of the electromagnetic field on seed germination, growth, and development indicators of Nigella sativa L. seeds. J. Plant. Res. 2015, 29, 867-873.

66. Ahmed, I.M.; Bassem, M.E. Effect of irrigation with magnetically treated water on faba bean growth and composition. Int. J. Agric. Policy Rec. 2013, 1, 24-40.

67. Mansour, E.R. Effect of Some Cultural Practices on Cauliflower Tolerance to Salinity under Ras Suder Conditions. Master's Thesis, Ain Shams University, Cairo, Egypt, 2007.

68. Hozayn, M.; Abdul Qados, A.M.S. Magnetic water technology, a novel tool to increase the growth, yield, and chemical constituents of lentil under greenhouse conditions. Am. Eurasian J. Agric. Environ. Sci. 2010, 7, 457-462.

69. Otsuka, I.; Ozeki, S. Does magnetic treatment of water change its properties? J. Phys. Chem. 2006, 110, 1509-1512. [CrossRef] 
70. Zamani, F.; Amirnia, R.; Rezaei-chiyaneh, E.; Rahimi, A. Evaluation of yield and yield components of Fennel (Foeniculum vulgare L.) with the combined application of nitrogen, phosphorus, and potassium supplier bacteria with mycorrhizal fungi in the low-input cropping system. Int. J. Agric. Sustain. 2017, 27, 217-231. (In Persian)

71. El-Abd, S.O.; El-Saied, H.M.; Mahmoud, M.H. Response of fennel (Foeniculum vulgare L.) on urea application rate under water deficit conditions in Cairo. Egypt. J. Hort. 2008, 54, 255-263.

72. Erdal, I.; Kepenek, K.; Kizilgos, I. Effect of foliar iron applications at different growth stages on iron and some nutrient concentrations in strawberry cultivars. Turk. J. Agric. For. 2004, 28, 421-427.

73. Nasiri, Y.; Salmasi, S.Z.; Nasrullahzadeh, S.; Najafi, N.; Ghassemi-Golezani, K. Effects of foliar application of micronutrients (Fe and $\mathrm{Zn}$ ) on flower yield and essential oil of chamomile (Matricaria chamomilla L.). J. Med. Plants Res. 2010, 4, $1733-1737$.

74. Campbell, G.S. An Introduction to Environmental Biophysics; Springer: New York, NY, USA, 1977.

75. Mihaela, R.; Dorina, C.; Carmen, A. Biochemical changes induced by low-frequency magnetic field exposure of vegetal organisms. Rom. J. Phys. 2007, 52, 645-651.

76. Mihaela, R.; Simona, M.; Dorina, E.C. The response of plant tissues to magnetic fluid and electromagnetic exposure. Rom. J. Biophys. 2009, 9, 73-82.

77. Sadeghipour, O.; Aghaei, P. Improving the growth of cowpea (Vigna unguiculata L. Walp.) by magnetized water. J. Biodivers. Environ. Sci. 2013, 3, 37-43.

78. Aladjadjiyan, A. The use of physical methods for plant growth stimulation in Bulgaria. J. Cent. Eur. Agric. 2007, 8, 369-380.

79. Aladjadjiyan, A. Study of the Influence of Magnetic Field on Some Biological Characteristics of Zea mays. J. Cent. Eur. Agric. 2002, 3, 89-94.

80. Racuciu, M.; Creanga, D.; Horga, I. Plant growth under static magnetic field influence. Rom. J. Phys. 2008, 53, 353-359.

81. Resteghar, S.; Sadeghi Lari, A. Effect of magnetized water on seed germination and early growth characteristics of tomato. Water Res. Agric. 2015, 29, 47-403.

82. Maie Mohsen, M.A.; Abeer Kassem, H.M. Influence of Magnetic Iron and Organic Manure on Fennel Plant Tolerance Saline Water Irrigation. Int. J. Pharmtech. Res. 2016, 9, 86-102.

83. Stang, B.; Rowland, R.; Rpley, B.; Podd, J. ELF magnetic field increase amino acid uptake into Vicia faba L. roots and alter ion movement across the plasma membrane. Bioelectromagnetics 2002, 23, 347-354. [CrossRef]

84. Nashir, S.H. The effect of magnetic water on the growth of chickpea. J. Eng. Technol. 2008, 26, 16-20.

85. Esitken, A.; Turan, M. Alternating magnetic field effects on yield and plant nutrient element composition of strawberry (Fragaria $x$ ananassa cv. Camarosa). Acta Agric. Scand. B Soil Plant Sci. 2004, 54, 135-139. [CrossRef]

86. Dhawi, F.; Al-Khayri, J.M. Magnetic fields induce changes in photosynthetic pigments content in date palm (Phoenix dactylifera L.) seedlings. Open Agric. 2009, 3, 1-5. [CrossRef]

87. Wojcik, S. Effect of the pre-sowing magnetic biostimulation of the buckwheat seeds on the yield and chemical composition of the buckwheat grain. Curr. Advan. Buckwheat. Res. 1995, 93, 667-674.

88. Samadyar, H.; Rahi, A.R.; Shirmohammadi, K.; Taghizade, F.; Kadkhoda, Z. The effects of electronic water filtration (magnetic water) on alkaloids hyoscine seeds and some morphological traits in two species of Datura. J. Plant. Ecosys. 2014, 10, 59-72. (In Farsi)

89. Nasreen, S.; Haque, M.M.; Hossain, M.A.; Farid, A.T.M. Nutrient uptake and yield of onion as Influence by nitrogen and sulfur fertilization. Bangladesh J. Agric. Res. 2007, 32, 413-420. [CrossRef]

90. El Sagan, M.A.M.; Abd El Baset, A. Impact of magnetic on metal uptake, quality and productivity in onion crop. J. Agric. Vet. Sci. 2015, 8, 2319-2372.

91. Darzi, M.T. Effects of organic manure and biofertilizer application on flowering and some yield traits of coriander (Coriandrum sativum). Int. J. Agric. Crop Sci. 2012, 4, 103-107.

92. Osman, E.A.M.; Abd El-Latif, K.M.; Hussien, S.M.; Sherif, A.E.A. Assessing the effect of irrigation with different levels of saline magnetic water on growth parameters and mineral contents of pear seedlings. Glob. J. Eng. Sci. Res. 2014, 2, 128-136.

93. Khazan, M.M.; Abdullatif, B.M. Effect of irrigation with magnetized water on growth, photosynthesis pigments and proline accumulation in jojoba (Simmondsia chinensis L.) seedlings. Saudi J. Biol. Sci. 2009, 16, 107-113.

94. Ottow, E.A.; Brinker, M.; Teichmann, T.; Fritz, E.; Kaiser, W.; Brosché, M.; Kangasjärvi, J.; Jiang, X.; Polle, A. Populus euphratica displays apoplectic sodium accumulation, osmotic adjustment by decreases in calcium and soluble carbohydrates, and develops leaf succulence under salt stress. Plant Physiol. 2005, 139, 1762-1772. [CrossRef] [PubMed]

95. Zerabi, M.M.; Mefakheri, S.; Kviani, A. Comparision of the effect of irrigation with ordinary and magnetic water on the morphological and physiological characteristic of corn under drought tension condition. Crop Physiol. J. 2017, 9, 39-54.

96. Grewal, H.S.; Maheshwari, B.L. Magnetic treatment of irrigation water and snow pea and chickpea seeds enhances seedlings early growth and nutrient contents. Bioelectromagnetics 2011, 32, 58-65. [CrossRef]

97. Hashemabadi, D.; Zaredost, F.; Jadid Solimandarabi, M. The Effect of Magnetic Water and Irrigation Intervals on the Amount of the Nutrient Elements in Soil and Aerial Parts of Periwinkle (Catharanthus roseus L.). J. Ornam. Plant. 2015, 5, 139-149.

98. Mohamed, H.M.; El-Kamar, F.A.; Abd-El-Elall, A.A.M. Effect of magnetite and some biofertilizer application on growth and yield of Valencia orange trees under El-Bustan condition. J. Nat. Sci. 2013, 11, 46-61.

99. Hasan, M.; Alharby, H.F.; Hajar, A.S.; Hakeem, K.R.; Alzahrani, Y. The Effect of Magnetized Water on the Growth and Physiological Conditions of Moringa Species under Drought Stress. Pol. J. Environ. Stud. 2019, 28, 1145-1155. [CrossRef] 
100. Abdul-Jaleel, C.; Manivannan, P.; Lakshmanan, G.M.A.; Gomathinayagam, M.; Panneerselvam, R. Alterations in morphological parameters photosynthetic pigment responses of Catharanthus roseus under soil water deficits. Colloids Surf. 2008, 61, 298-303. [CrossRef]

101. Darzi, M.T.; Ghalavand, A.; Rejali, F. Effect of mycorrhiza, vermicompost and phosphate biofertilizer application on flowering, biological yield and root colonization in fennel (Foeniculum vulgare Mill.). Iran. J. Crop Sci. 2008, 10, 88-109.

102. Younesian, A.; Taheri, S.; Moghaddam, P.R. The effect of organic and biological fertilizers on the essential oil content of Foeniculum vulgare Mill. (Sweet Fennel). Int. J. Agric. Crop Sci. 2013, 5, 2141-2146.

103. Baydar, H.; Sagdic, O.; Ozkan, G.; Karadogan, T. Antibacterial activity and composition of essential oils from Origanum, Thymbra, and Satureja species with commercial importance in Turkey. Food Control J. 2004, 15, 169-172. [CrossRef]

104. Bettaieb, I.; Zakhama, N.; Aidi-Wannes, N.; Kchouk, M.E.; Marzouk, B. Water deficit effects on Salvia officinalis fatty acids and essential oils composition. Sci. Hortic. 2009, 120, 271-275. [CrossRef]

105. Novak, J.; Grausgruber, H.; Pank, F.; Langbehn, J.; Blüthner, W.D.; Vender, C.; Niekerk, L.V.; Junghanns, W.; Franzl, C. Stability of Hybrid combinations of Marjoram (Origanum majorana L.). Flavour Fragr. J. 2003, 18, 401-406. [CrossRef]

106. Gupta, V.; Mittal, P.; Bansal, P.; Khokra, S.L.; Kaushik, D. Pharmacological potential of Matricaria recutita: A review. Int. J. Pharm. Sci. Res. 2006, 2, 12-16.

107. Kapoor, R.; Giri, B.; Mukerji, K.G. Improved growth and essential oil yield and quality in Fennel (Foeniculum vulgare Mill) on mycorrhizal inoculation supplemented with P-fertilizer. Bioresour. Technol. 2004, 93, 307-311. [CrossRef]

108. Anwar, M.; Patra, D.D.; Chand, S.; Alpesh, K.; Naqvi, A.A.; Khanuja, S.P.S. Effect of organic manures and inorganic fertilizer on growth, herb and oil yield, nutrient accumulation, and oil quality of French basil. Commun. Soil Sci. Plant. Anal. 2005, 36, 1737-1746. [CrossRef] 